\title{
Influence of temperature and atmosphere on the strength and elastic modulus of solid oxide fuel cell anode supports
}

Ni, De Wei; Charlas, Benoit; Kwok, Kawai; Tadesse Molla, Tesfaye; Hendriksen, Peter Vang; Frandsen, Henrik Lund

Published in:

Journal of Power Sources

Link to article, DOI:

10.1016/j.jpowsour.2016.02.027

Publication date:

2016

Document Version

Peer reviewed version

Link back to DTU Orbit

Citation (APA):

$\mathrm{Ni}$, D. W., Charlas, B., Kwok, K., Tadesse Molla, T., Hendriksen, P. V., \& Frandsen, H. L. (2016). Influence of temperature and atmosphere on the strength and elastic modulus of solid oxide fuel cell anode supports. Journal of Power Sources, 311, 1-12. https://doi.org/10.1016/j.jpowsour.2016.02.027

\section{General rights}

Copyright and moral rights for the publications made accessible in the public portal are retained by the authors and/or other copyright owners and it is a condition of accessing publications that users recognise and abide by the legal requirements associated with these rights.

- Users may download and print one copy of any publication from the public portal for the purpose of private study or research.

- You may not further distribute the material or use it for any profit-making activity or commercial gain

- You may freely distribute the URL identifying the publication in the public portal 


\section{Highlights in this work}

- Bending test of high number of samples $(\sim 30)$ was performed at different conditions.

- Influence of reduction temperature on mechanical properties of Ni-YSZ was revealed.

- Temperature dependence of mechanical properties of Ni(O)-YSZ was revealed.

- Failure in Ni-YSZ is determined by YSZ; while it is determined by NiO in NiO-YSZ. 


\title{
Influence of temperature and atmosphere on the strength and elastic modulus of solid oxide fuel cell anode supports
}

\author{
De-Wei Ni ${ }^{1, *}$, Benoit Charlas ${ }^{1}$, Kawai Kwok ${ }^{1}$, Tesfaye Tadesse Molla ${ }^{1}$, Peter Vang Hendriksen ${ }^{1}$, and \\ Henrik Lund Frandsen ${ }^{1}$ \\ ${ }^{1}$ Department of Energy Conversion and Storage, Technical University of Denmark, Ris $\varnothing$ Campus, \\ Frederiksborgvej 399, DK-4000 Roskilde, Denmark. \\ *Corresponding author: dwei@dtu.dk, Tel: +45 9351-1097, Fax: +45 4677-5858
}

\begin{abstract}
:
Solid Oxide Fuel Cells are subjected to significant stresses during production and operation. The various stress-generating conditions impose strength requirements on the cell components, and thus the mechanical properties of the critical load bearing materials at relevant operational conditions need to be characterized to ensure reliable operation.

In this study, the effect of reduction temperature on microstructural stability, high temperature strength and elastic modulus of Ni-YSZ anode supports were investigated. The statistical distribution of strength was determined from a large number of samples $(\sim 30)$ at each condition to ensure high statistical validity. It is revealed that the microstructure and mechanical properties of the Ni-YSZ strongly depend on the reduction temperature. Further studies were conducted to investigate the temperature dependence of the strength and elastic modulus for both the unreduced and reduced Ni(O)-YSZ anode supports. With increasing temperature, the strength and elastic modulus of the reduced Ni-YSZ specimens drop almost linearly. In contrast, the strength and elastic modulus of the unreduced NiO-YSZ remain almost constant over the investigated temperature range. Compared to the NiO-YSZ, a significantly lower strength and elastic modulus of the reduced Ni-YSZ is observed; while reduction leads to a remarkable increase in failure strain of the anode support.
\end{abstract}


Key Words: Mechanical properties; Strength; Elastic modulus; Anode support; Reduction, Ni-YSZ.

\section{Introduction}

Solid Oxide Fuel Cells (SOFCs) are electrochemical devices that convert the chemical energy of fuel (hydrogen, natural gas, etc.) directly to electrical energy. They have been intensively studied due to the high efficiency and potential for low cost $[1,2]$. Until now, the most commonly used planar SOFCs are mechanically supported by the anode (fuel electrode) material. The most widely used anode support for SOFCs is a porous ceramic-metal composite (cermet) consisting of nickel and yttria stabilized zirconia

(Ni-YSZ) [1,3]. Generally, porous Ni-based anodes and anode supports are fabricated starting with YSZ and $\mathrm{NiO}$ (NiO-YSZ), which is chemically reduced to $\mathrm{Ni}$-YSZ through the introduction of fuel, leading to the formation of the required porosity and an electronically conducting Ni-network. Depending on temperature, reductant and water content of the reduction gas, full reduction can be achieved in time intervals spanning from a few minutes to hours, with higher temperature promoting faster reduction kinetics. The reduction process can significantly influence the microstructure of the cermet, and consequently its performance and mechanical stability [4-7].

With the implementation of the single cells into stacks and products, their reliability has received increasing attention $[7,8]$. The reliability of SOFCs is dependent not only on the chemical and electrochemical stability of its components, but also on the capability of the SOFC components to withstand mechanical stresses that arise during production and operation. The stresses in a cell embedded in a stack have different origins, e.g. thermal expansion mismatch between the anode and electrolyte and between cell and interconnect, assembly forces, reduction and oxidation reactions, and intrinsic stresses arising from nonhomogeneous temperature distribution during operation $[7,8]$. In practical application, the integrity of the cells is crucial, since mechanical failure severely influence the performance, and could 
lead to overall failure of the system. Therefore, assessment of the mechanical properties of the SOFC components is important, particularly under conditions relevant for operation. This enables quantification of stresses and is required to understand reliability issues, and in developing fail safe cell- and stackdesigns.

To evaluate the mechanical reliability, the stresses under operation of the SOFC stacks must be assessed together with the material resistance to failure. Typically, a statistical approach (Weibull distribution) is preferred to assess the distribution of the strength of brittle components at operational conditions; as it offers simple experiments and stress analysis [5-13]. The drawback is however that strength measurements of as many as 30 samples under the same condition are needed to get a good statistical representation and avoid large uncertainty on parameter estimates, as pointed out by Khalili and Kromp [14]. All cells will already have experienced loads (a "base load"), from various processes in the production, which will make a few cells fail. Thus, a three-parameter Weibull distribution is perhaps a better representation of the population, as the third parameter is lower limit to strength representing this base load. A three-parameter Weibull distribution does however require an even higher number of specimens $(\sim 100)[11,15]$.

The strength of $\mathrm{Ni}(\mathrm{O})-\mathrm{YSZ}$ composites has received much attention as this is the main structural component in the anode supported cell design, and various effects of the processing, reduction of the Ni phase, size effects and redoxing has been investigated at room temperature. Radovic and Lara-Curzio [6] studied the dependence of strength on porosity at room temperature for both Ni-YSZ and NiO-YSZ, where the property-porosity trends were found to be in good agreement with predictions of the minimum solid area model. Frandsen et al [12] showed that this was also valid even regardless of what process parameters were varied resulting in the variations in porosity.

Faes et al [16] compared tensile uniaxial and ball-on-ring strength measurements of as-sintered NiO-YSZ anode materials. In spite of the great variation in measured strength from the two methods, the results were shown to be comparable given the strength scaling with so-called effective volume. Biswas et 
al [17] also reported an influence of thickness $(600-900 \mu \mathrm{m})$ on strength of anode supported half-cells. The strength was comparable in the oxidized condition but differed in the reduced condition, which was tentatively ascribed to an un-even reduction of the thicker sample. Moreover, the reduced half-cell structures characterized by a higher porosity presented a higher strength compared to the unreduced ones in their work, which is contrary to other results in the literature [5-7]. The reason could be that residual stresses of the tested half-cells were not considered in the characterizations. The decrease of strength and elastic modulus after reduction as observed in Ref. [5-7] is ascribed predominantly to the associated increased porosity by reduction. Moreover, it is found that the strength of the Ni-based anode materials can be influenced by reduction parameters [5]. Faes et al [18] measured the strength of half-cells at room temperature for reduction temperatures of $600{ }^{\circ} \mathrm{C}$ and $1000{ }^{\circ} \mathrm{C}$ and enhanced strength was observed at higher reduction temperature.

In partially stabilized 3YSZ sub-critical crack growth may occur and the strength of $\mathrm{Ni}(\mathrm{O})-3 \mathrm{YSZ}$ may thus be load rate dependently, see e.g. $[19,20]$. Hashida et al $[21,22]$ also showed that plastic deformations occurred before fracture in their Ni-YSZ cermet given a sufficient slow loading rate.

The temperature dependence of the elastic modulus of both as-sintered and reduced $\mathrm{Ni}(\mathrm{O})-\mathrm{YSZ}$ composites has been studied by Pihlatie and Biswas et al [17, 23, 24]. A peaking of stiffness was observed to coincide with the Néel temperature of $\mathrm{NiO}$ in the as-sintered state and above this temperature, a slight decrease occurred. In the reduced state the elastic modulus decreased linearly with temperature.

The strength of $\mathrm{Ni}(\mathrm{O})-\mathrm{YSZ}$ at high temperature has been measured at $800{ }^{\circ} \mathrm{C}$ in a few studies $[7$, $15,21,22]$, and it has commonly been shown that the strength is reduced relative to room temperature. The strength at $800{ }^{\circ} \mathrm{C}$ in the oxidized state was shown to be reduced relative to room temperature by $13 \%$ and $27 \%$ in [7] and [15], respectively, and by $20 \%$ in reduced state [15]. However, only in one case [7] a high number of samples (30) were tested in the oxidized state at high temperature, allowing a reliable determination of the Weibull modulus. In the other works typically only the average strength has been 


\section{Experimental procedures}

\subsection{Materials}

The anode supports tested in this study were prepared from a mixture of commercial nickel-oxide $(\mathrm{NiO})$ and $3 \mathrm{~mol} \% \mathrm{Y}_{2} \mathrm{O}_{3}$ stabilized $\mathrm{ZrO}_{2}$ (YSZ) powders using standard ceramic processing including tape casting and sintering, see e.g. Ref. [25]. The composition of the NiO-YSZ anode support was 55 wt\% 
$\mathrm{NiO}$ with $45 \mathrm{wt} \% \mathrm{YSZ}$. The as-sintered anode support had dimensions of approximately $120 \times 120 \times 0.3$ $\mathrm{mm}^{3}$ with a porosity of around $13 \%$. Rectangular samples of $7.3 \mathrm{~mm}$ by $60 \mathrm{~mm}$ were laser cut from the as-sintered NiO-YSZ material. In order to ensure reproducibility, the samples to be characterized were stacked and glued together with epoxy, and then polished. By this procedure a surface finish of approximately $1 \mu \mathrm{m}$ is achieved and edge defects are effectively removed, as the defects from the laser cutting branches approximately 5-10 $\mu \mathrm{m}$ into the NiO-YSZ support [26]. After polishing the epoxy was removed by acetone. The resulting polished samples had a dimension of around $7.0 \mathrm{~mm}$ by $60 \mathrm{~mm}$.

\subsection{Testing procedures}

In this work, the influence of both reduction temperatures and testing temperatures on the strength of $\mathrm{Ni}(\mathrm{O})$-YSZ anode supports were studied. Thus, two different sets of experiments were carried out:

I. Influence of reduction temperature: Samples were reduced at 4 different conditions: $700{ }^{\circ} \mathrm{C}(8 \mathrm{~h}), 800$ ${ }^{\circ} \mathrm{C}(6 \mathrm{~h}), 900{ }^{\circ} \mathrm{C}(4 \mathrm{~h})$ and $1000{ }^{\circ} \mathrm{C}(2 \mathrm{~h})$ in $9 \% \mathrm{H}_{2}-91 \%$ Ar. After reduction, bending tests were conducted at $800{ }^{\circ} \mathrm{C}$ under reducing conditions.

II. Influence of testing temperature: Bending tests were conducted over the temperature range from room temperature to $800{ }^{\circ} \mathrm{C}$ on both as prepared and reduced samples. In this test series, reduction was carried out at $800{ }^{\circ} \mathrm{C}(6 \mathrm{~h})$ and bending tests of reduced samples were conducted in $9 \% \mathrm{H}_{2}-91 \% \mathrm{~N}_{2}$. Unreduced samples were tested in air.

All the reduction experiments were conducted in a tube furnace with $9 \% \mathrm{H}_{2}$-Ar as reductant, which was introduced only once the specimens had reached the desired reduction temperatures. The bending tests were conducted with an in-house built high temperature 4-point bending rig in which up to 16 samples can be tested in one heat up with controlled atmosphere. In this rig, the span between the two inner loading pins is $25 \mathrm{~mm}$ and the span between the two outer support pins is $50 \mathrm{~mm}$. More details 


\subsection{Mechanical analysis}

The stress field inside the samples can be calculated by use of thin beam theory using the measured load-displacement curves in the 4-p bending experiments. However, the stress varies across the sample which is not captured by the beam theory, see Fig. 1. Thus, both the maximum stress and socalled effective volume will be in-accurately determined using the beam theory. In this work, the strength was therefore determined for each sample by large displacement finite element simulations (FEM), whereby the maximum first principal stress and the effective volume can be accurately determined.

The load displacement curves were found to be linear at all investigated temperatures and atmospheres, and thus the material behavior in the FEM has been assumed to be elastic. In other works (e.g. Hashida et al $[21,22])$ a significant non-linear load-displacement curve for Ni-YSZ cermets was found when tested under reducing conditions [21,22]. This is probably due to the higher loading rate used in the present work $(0.5 \mathrm{~mm} / \mathrm{min}$ in this work; $0.05 \mathrm{~mm} / \mathrm{min}$ in Refs. [21, 22]), which results in smaller influence from primary creep [28]. However, since we did not load "infinitely" fast a small plastic 
deformation of the different phases in the composites could occur. Especially the Ni phase is creeping fast at high temperature. The linearity of the load-displacement curves together with the abrupt failure reveals that the YSZ phase remains elastic and brittle throughout the experiments. And therefore, strength in the Ni-YSZ composite is defined by when the YSZ phase experiences its maximum load capacity; and similarly, the strain in the Ni-YSZ composite is defined by the maximum strain of the YSZ phase.

As mentioned above, the strength of brittle components is highly dependent on the distribution of flaws within the material and Weibull statistical analysis is preferred to quantify this distribution. The probability of failure $P_{f, t h}$ in the Weibull distribution characteristic of the largest occurring tensile stress $\left(\sigma_{\max }\right)$ is described by $[9,10,29-31]$ :

$$
P_{f, t h}=1-\exp \left(-\frac{1}{\sigma_{0} V_{\text {eff }}} \int_{V}\left(\sigma_{1}^{m}+\sigma_{2}^{m}+\sigma_{3}^{m}\right) d V\right)=1-\exp \left(-\left(\frac{\sigma_{\max }}{\sigma_{0}}\right)^{m}\right)
$$

Where $m$ and $\sigma_{0}$ are the Weibull modulus and Weibull strength, respectively characterizing the distribution, and $V_{\text {eff }}$ is the effective volume defined by Eq. (3). The multi-axial stress field is taken into account by use of the multi-axial Weibull theory, where the stress variation is accounted for by integrating each of the different principal stress components $\left(\sigma_{1}, \sigma_{2}\right.$ and $\left.\sigma_{3}\right)$ independently over the entire volume of the samples [29-31]. Experimentally, the probability of failure $\left(P_{f, e x}\right)$ assigns a probability of failure between 0 and 1 to all of the recorded stresses at failure in ascending order [14]:

$$
P_{f, e x}=\frac{i-0.5}{N}
$$

The calculated stress at failure for the $N$ samples are ranked in ascending order, $i=1,2,3 \ldots, N$, where $N$ is the total number of the tested samples in each batch. The Weibull modulus $(m)$ and characteristic strength $\left(\sigma_{0}\right)$ was obtained by linear least squares regression of the experimental data $\left(P_{f}, \sigma_{i}\right)$ with the distribution defined by Eq. (1). The effective volume $V_{\text {eff }}$ can according to the multi-axial Weibull theory, be obtained by integrating the axial tensional stresses over the volume of the sample [31] 
The strength analysis outlined above assumes that the weakest spot under tension determines the strength of the component. One should always consider $V_{\text {eff }}$ when analyzing strength and when comparing reported strength obtained by different methods as larger specimens or larger $V_{\text {eff }}$ have greater probability of containing a larger, more severe flaw. Otherwise the measured strength from a smaller tested volume could give a wrong impression of a stronger material. The Weibull weakest-link model leads to a strength dependency on component size $[9,10,32]$ :

$$
\frac{\sigma_{0}^{\prime}}{\sigma_{0}^{\prime \prime}}=\left(\frac{V_{e f f}^{\prime \prime}}{V_{e f f}^{\prime}}\right)^{1 / m}
$$

where $\sigma_{0}$ ' and $\sigma_{0}{ }^{\prime \prime}$ are the characteristic strengths of specimens for type 1 and 2 (which have different dimensions), $V_{\text {eff }}$ and $V_{\text {eff }}$ ' represent respective effective volumes. In order to compare the strength measurements, they should be scaled to a similar effective volume, using the Eq. (4). In this work, all the characteristic strengths presented were scaled to an effective volume of $1 \mathrm{~mm}^{3}$.

Elastic moduli $(E)$ were determined from the slope of the load-displacement $(\Delta P / \Delta d)$ curves in 4point bending test according to [33]:

$$
E=\frac{3 L a^{2}-4 a^{3}}{12 I} \cdot \frac{\Delta P}{\Delta d}
$$

where $a$ is the distance between the loading points and the support points, and $I$ is the moment of inertia defined here by $I=w h^{3} / 12(L, w, h$ are the length, width and height of the specimens, respectively). The specimen dimensions ( $a, w$, and $L$ ) shown in Eq. (5) are also indicated in Fig. 1a. Failure strain $\left(\varepsilon_{0}\right)$ is determined by $\left(\varepsilon_{0}=\sigma_{0} / E\right)$. 


\section{Results and discussion}

\subsection{Influence of reduction temperature on strength of Ni-YSZ anode supports}

The NiO-YSZ specimens were reduced at either $700,800,900$ or $1000{ }^{\circ} \mathrm{C}$. To ensure that all the specimens are fully reduced at each reduction temperature, the reduction period varied with temperatures; $8 \mathrm{~h}, 6 \mathrm{~h}, 4 \mathrm{~h}$ and $2 \mathrm{~h}$, at $700,800,900$ and $1000{ }^{\circ} \mathrm{C}$ respectively. After reduction, 4-point bending tests were performed at $800{ }^{\circ} \mathrm{C}$ in $9 \% \mathrm{H}_{2}\left(\mathrm{~N}_{2}\right.$ balance). Regardless of the reduction temperatures, the weight loss of the Ni-YSZ anode supports during reduction is around $11.8 \%$ for all the specimens, which indicates that the anode supports were fully reduced, according to the chemical composition of the NiO-YSZ anode support. All the specimens were taken from the same batch, which had a porosity of $13 \%( \pm 0.1 \%)$ before reduction. After reduction, the porosity was $\sim 36 \%$ for all the samples.

The strength measurements of the samples reduced at different temperatures are shown in Fig. 2a together with the fitted Weibull probability distributions. The correlation coefficients $\left(R^{2}\right)$ are higher than 0.97 for all the 4 sets of data, indicating that the Weibull distribution represents the data well. The corresponding Weibull parameters are provided in Table 1 together with the elastic moduli $(E)$. The scaled characteristic strength $\left(\sigma_{0}{ }^{\prime}\right)$ (see section 2.3) of the reduced anode support is higher than $120 \mathrm{MPa}$, and the elastic moduli $(E)$ are in the range between 30.7 and $37.8 \mathrm{GPa}$, depending on reduction temperatures. The Weibull moduli $(m)$ are higher than 12. As stated above, a surface finish of approximately $1 \mu \mathrm{m}$ was achieved after polishing, whereby the edge defects were effectively removed. Thus, the high Weibull moduli indicate that the intrinsic flaws of the porous anode are evenly distributed and thus that the ceramic processing is of good quality.

Only small differences of strengths and elastic moduli are observed among the Ni-YSZ anode supports reduced under different conditions, as shown in Table 1. However, the characteristic strengths for the 900 and $1000{ }^{\circ} \mathrm{C}$ reduction lie respectively $4 \%$ and $12 \%$ above the values recorded at the reduction at 700 or $800{ }^{\circ} \mathrm{C}$ (Table $\mathbf{1}$ and Fig. 2b). This is presumably related to microstructural differences and shows that although complete reduction and similar porosity are obtained for the samples under different 
reduction conditions, reduction temperatures can influence the microstructure characteristics of Ni-YSZ and consequently the strength. Enhanced strength at higher reduction temperature has also been reported in Ref. [18], where the characteristic strength of half-cells (tested at room temperature) increased from $318 \mathrm{MPa}$ to $361 \mathrm{MPa}$ as reduction temperature increased from $600{ }^{\circ} \mathrm{C}$ to $1000{ }^{\circ} \mathrm{C}$, as also listed in Table 1.

The failure strain $\left(\varepsilon_{0}=\sigma_{0} / E\right.$ ) is perhaps an even more interesting quantity describing the mechanical performance of the cell than the strength, because during operation the main mechanical load on the cells stems from differences in thermal expansions over the cell plane (and stack volume), which are governed by the uneven temperature distribution that establishes due to uneven reaction rates and heat transportations by the gasses. The importance of failure strain has also been realized in other works on energy materials $[12,34]$. For an unconstrained cell the strain field is independent of the elastic moduli of the cell materials. In other words, the cell has to withstand a certain strain field rather than a specific stress. As seen in Table 1 and Fig. 2b, the failure strain varies only mildly over the four different sets and shows a maximum of $0.40 \%$ for the cells reduced at $900{ }^{\circ} \mathrm{C}$. It is noteworthy that all the failure strains recorded are relatively high (0.36-0.40\%), and comparable to the reported values of pure YSZ by Deng et al [35].

To better understand the influence of reduction temperatures on microstructure evolution during reduction, the polished cross sections of the reduced Ni-YSZ anode supports were investigated. Fig. 3 shows the SEM images of the Ni-YSZ anode supports reduced at different temperatures, together with the unreduced NiO-YSZ. From image analysis by ImageJ, the porosity of the unreduced NiO-YSZ specimen is determined to be around $13 \%$, which increases to $\sim 36 \%$ after reduction, regardless of the reduction temperatures, in good agreement with the weight loss measurements. Even with increased porosity, the phases are still well connected in the reduced specimens.

Energy Dispersive Spectroscopy (EDS) was used to identify different phases: YSZ, NiO, and Ni. In the unreduced specimen (Fig. 3a), the darker areas are $\mathrm{NiO}$ and the white parts are YSZ. After 

measured porosity is around $36 \%$ for all the specimens reduced at different temperatures, which is consistent with the values obtained by image analysis. It is found that the pore size distribution of all the specimens is mono-modal. However, the average pore size clearly increases from $0.35 \mu \mathrm{m}$ to $0.60 \mu \mathrm{m}$ as the reduction temperature increases from $700{ }^{\circ} \mathrm{C}$ to $1000{ }^{\circ} \mathrm{C}$. It should be noted that the pore size diameters given by the porosimetry are the entry diameters to pores and do not always give a true quantitative representation, but are valuable for comparison between samples as it represents an integral quantity.

According to the Griffith criterion [36, 37], the fracture of brittle materials results from the propagation of cracks from critical defects, which preexists in the sample resulting from some steps in the manufacturing process. In porous material, the pores generally act as stress concentrators to higher degree than e.g. large particles in a composite, as the change in stiffness is larger from pore to solid than that from one solid to another solid. Compared to pore size, the shape of the pores plays a more critical role in determination of the stress field within the porous component. As all the specimens investigated in this work were taken from the same batch, it can be reasonably assumed that the critical defect size and shape are comparable before reduction. During reduction at high temperature, diffusion among the newly formed Ni particles is promoted as temperature increases, which results in larger pores at higher reduction 
temperatures. Moreover, it is also expected that the promoted diffusion at higher temperature among Ni particles is beneficial for healing some of the defects or flaws within the material, e.g. by smoothening micro notches via sintering, as these notches constitute high surface area per volume domains of the microstructure. It is assumed that fewer and smoothened defects are present in the specimens reduced at higher temperature even though this is not evident from the SEM images. The complexity of the microstructure makes it difficult to quantify the defect concentrations. The tendency of improved strength and enhanced elastic modus at elevated reduction temperature supports the postulate that fewer and smoothened defects are present in the specimens reduced at higher temperature. Such healing effect of defects and consequent strength improvement after high temperature treatment has also been reported in other structural ceramics [38-40].

On the other hand, it has recently been shown that at the point of reduction all residual stresses in the $\mathrm{Ni}(\mathrm{O})-\mathrm{YSZ}$ structure are effectively removed [28], and compressive residual stress will thus be accumulated in the YSZ structure during cooling down after reduction, due to the smaller thermal expansion coefficient of YSZ $\left(11 \times 10^{-6} \mathrm{~K}^{-1}\right)$ [7] compared to Ni $\left(16 \times 10^{-6} \mathrm{~K}^{-1}\right)$ [41]. The YSZ framework provides the main mechanical strength in the Ni-YSZ composites. Therefore, the anode supports reduced at higher temperature $\left(900{ }^{\circ} \mathrm{C}\right.$ and $\left.1000{ }^{\circ} \mathrm{C}\right)$ should benefit from the compressive residual stress, resulting in improved strength. While for the samples reduced at temperatures lower or equal to the testing temperature, residual stresses build up which could potentially decreases the strength of the anode support (the latter is not observed experimentally). Whereas the residual stresses can thus account for the trend in the observations, that samples reduced at 900 and $1000{ }^{\circ} \mathrm{C}$ are slightly stronger than the samples reduced at $800{ }^{\circ} \mathrm{C}$; but they cannot account for the observation of no variation in strength between the samples reduced at $700{ }^{\circ} \mathrm{C}$ and $800{ }^{\circ} \mathrm{C}$. (see Table 1 and Fig. 2b).

Nonetheless, it should be pointed out that conditioning of a SOFC stack (including reduction) at temperatures higher than $800{ }^{\circ} \mathrm{C}$ could be a challenge when using commercial steels as Crofer 22 APU for the interconnects, as the corrosion rate and grain growth rate increases strongly above this temperature 
[42]. Thus, the potential strength gain of $12 \%$ that can be achieved through reduction at $1000{ }^{\circ} \mathrm{C}$ may not be overall advantageous for the stack. For this reason a reduction temperature of $800{ }^{\circ} \mathrm{C}$ is chosen as the reference reduction temperature for the following study of the temperature dependency of the strength of the reduced anode support.

\subsection{Influence of temperature on strength of reduced/unreduced anode supports}

As discussed in the previous section increasing the temperature where reduction takes place has a small positive impact on anode support strength and thus the reliability of the stack. Also the maximum temperature experienced during stack assembly and the temperature of operation will affect the mechanical reliability of the stack, and hence it is important to study their effect on anode support strength. In this section, the influence of temperature on strength was investigated for both the reduced $\mathrm{Ni}-\mathrm{YSZ}$ (reduced @ $800{ }^{\circ} \mathrm{C}$ ) and unreduced NiO-YSZ anode supports. Fig. 5 shows the Weibull plots of the specimens tested over the temperature range from room temperature to $800{ }^{\circ} \mathrm{C}$ for both the reduced and as-prepared anode supports. Again each point represents the Weibull statistics of approximately 30 samples. The Weibull parameters and elastic moduli are shown in Table $\mathbf{2}$ and Table $\mathbf{3}$, for reduced and unreduced samples respectively. The variation of Weibull strength (scaled to $V_{\text {eff }}=1 \mathrm{~mm}^{3}$, see Eq. (4)), failure strains and elastic moduli with temperature are also plotted in Fig. 6.

As all the specimens were taken from the same batch and supports with the same porosity were carefully picked, the inherent flaw distributions and hence the Weibull moduli were a priori expected to be similar at all testing temperatures. This is however not the case, the Weibull moduli show some difference among the tests conducted at different temperatures, especially for the unreduced specimens (Table 3). Owing to the statistical nature of the strength of ceramic materials, the Weibull parameters determined from a finite number of specimens $(\sim 30)$ may unavoidably show some deviation from that of the parent population. The uncertainty in the measured Weibull parameters can be assessed by means of Monte Carlo simulations [13, 14, 43, 44]. In addition to finite sampling, measurement uncertainty also 
influences the accuracy of the measured Weibull parameters. The total uncertainties (finite sample number and effects of measurement uncertainty) in Weibull moduli and Weibull strength were estimated with a confidence interval of $90 \%$ and given in Tables 1-3. While for elastic modulus, it is difficult to estimate the uncertainty in this work; instead, the standard deviation for each series of measurements was given. And the uncertainty in failure strain was estimated accordingly, based on the uncertainty/standard deviation in Weibull strength and elastic modulus also by use of Monte Carlo simulations. Considering the observed variation in view of these uncertainties it is concluded that the variation of strength and elastic modulus with temperature and reduction temperature is statistically significant whereas the differences of the Weibull moduli at different testing temperatures (Tables $\mathbf{2}$ and $\mathbf{3}$ ) are not. It can thus be concluded that new defect types do not seem to appear with temperature variation (e.g. from internal residual stress release between the phases). Therefore investigations of high temperature properties in this system can be limited to the number of samples needed for obtaining an accurate Weibull strength rather than to the number dictated by accurate assessment of the Weibull modulus, as this was not observed to change significantly with temperature. Even so, it should still be pointed out that a practical number of strength tests should be performed to obtain a desired level of confidence associated with a parameter estimate. The number of test specimens needed depends on the precision required in the resulting parameter estimate. Details relating to the computation of confidence bounds can be found in Refs [43, 45]. As an illustration, with the modulus characteristic of the samples studied here, to detect a $10 \%$ difference in $\sigma_{0}$ (as found here between the $1000{ }^{\circ} \mathrm{C}$ reduction and $800{ }^{\circ} \mathrm{C}$ reduction) with a confidence of $90 \%$ requires 7 samples; a difference of $20 \%$ could be detected with the same level of confidence with 2 samples; whereas a difference of $5 \%$ requires 29 samples (estimated by use of Monte-Carlo simulations as in Ref. [43]).

In order to compare the strength properly, the strengths presented in Fig. 6 were scaled to the same effective volume of $1 \mathrm{~mm}^{3}$ (see also $\sigma_{0}$ ' in Table 2 and Table 3). The strength of the reduced anode supports shows a linear decrease with increasing testing temperature from room temperature to $800{ }^{\circ} \mathrm{C}$, 
from $\sim 268 \mathrm{MPa}$ at room temperature to $\sim 121 \mathrm{MPa}$ at $800{ }^{\circ} \mathrm{C}$, as shown in Table 2 and Fig. 6. The failure strain of the reduced anode supports first increases from $0.34 \%$ at room temperature to $\sim 0.44 \%$ at $600{ }^{\circ} \mathrm{C}$, and then decreases to $0.39 \%$ at $800{ }^{\circ} \mathrm{C}$. The failure strains of reduced Ni-YSZ in this work are comparable to the reported values of pure YSZ [35], which are also similar to the calculated values based on the reported strength and elastic modulus in Ref. [22], as shown in Table 2. The degradation of strength of ceramics at elevated temperature generally relates to the softening of grain boundaries or secondary phase $[46,47]$. According to Griffith theory [37], the strength $\sigma$ of a material is dependent on a number of properties, as shown in Eq. (6):

$$
\sigma=\alpha\left(\frac{2 E \gamma_{s}}{c}\right)^{1 / 2}
$$

Where $\alpha$ is defect shape factor, $\gamma_{s}$ is the fracture energy and $c$ is the defect size. In general as temperature increases the interatomic distance increases, and consequently, the bond stiffness between atoms will be reduced. Macroscopically, this corresponds to a reduced elastic modulus at elevated temperature. This is particularly so for phases with low melting point, such as glass phases and metallic phases ( $\mathrm{Ni}$ in this work) [48], explaining the observed decrease in elastic moduli of the Ni-YSZ samples reported in Table 2 and Fig. 6, which decreases $61 \%$ from $\sim 78.3 \mathrm{GPa}$ at room temperature to $\sim 30.7 \mathrm{GPa}$ at $800{ }^{\circ} \mathrm{C}$. The degradation of strength is primarily due to a decrease in elastic modulus with temperature, but also the increase of ductility and thus a decrease in load bearing capacity of the Ni phase at elevated temperature may contribute to the strength reduction. A direct verification of this would require measuring the fracture energy or fracture toughness at different temperatures. According to Eq. (6), an estimate of the fracture energy can be obtained roughly from the measured characteristic strength and elastic modulus, which is proportional to $\sigma_{0}{ }^{2} / \mathrm{E}$. The values of $\sigma_{0}{ }^{2} / \mathrm{E}$ for the reduced specimens tested at different temperatures are shown in Table 2. It is found that $\sigma_{0}{ }^{2} / \mathrm{E}$ drops from $0.92 \mathrm{MPa}$ at room temperature to $\sim 0.48 \mathrm{MPa}$ at $800{ }^{\circ} \mathrm{C}$. Even though $\sigma_{0}{ }^{2} / \mathrm{E}$ is a rough estimate of fracture energy, it can still 
give a qualitative comparative measure of the energy needed to propagate a critical flaw. In the Ni-YSZ composites here studied the fracture energy is thus observed to decrease with increasing temperature.

Compared to the reduced anode supports, the unreduced specimens show much higher strength and elastic moduli, but significantly lower failure strains over the investigated temperature range (Table 3 and Fig. 6). When considering the strength measured at room temperature, the reduced anode supports at room temperature $\left(\sim 268 \mathrm{MPa}, V_{\text {eff }}=1 \mathrm{~mm}^{3}\right)$ is approximately $36 \%$ weaker than the unreduced specimens ( $421 \mathrm{MPa})$, as a consequence of the reduction process. The strength and elastic moduli decrease due to reduction becomes more significant at elevated temperatures. A number of studies [5-7] have shown that the reduction process has a large influence on the strength and elastic modulus of Ni-containing composites due to the change of microstructure, with the main cause being the increase in porosity. It can also be seen that the temperature dependence of the strengths, the elastic modulus and the failure strains of the as-prepared anode supports is very different from those observed for the reduced samples. Almost no change of strengths, elastic moduli and failure strains is observed for the unreduced anode supports over the testing temperature range from room temperature to $800{ }^{\circ} \mathrm{C}$ (Table $\mathbf{3}$ and Fig. 6).

The temperature dependence of the elastic modulus of $\mathrm{Ni}(\mathrm{O})-\mathrm{YSZ}$ anode materials is well described in literature, showing fairly similar trends $[17,23,24]$. The elastic modulus in oxidized state (NiO-YSZ) exhibits a peak at temperature around $250-330{ }^{\circ} \mathrm{C}$ related to the antiferromagnetic to paramagnetic transition of $\mathrm{NiO}$, followed by a slight decrease (less than $3 \%$ upto $800{ }^{\circ} \mathrm{C}$ ), though a shift in temperature appears when comparing the data between [23] and [24]. In the reduced state the elastic modulus decreased linearly with temperature. The range of reported variations in elastic moduli for common anode materials is very large, between 79 and $207 \mathrm{GPa}$ for NiO-YSZ and 18-98 GPa for the reduced $\mathrm{Ni}-\mathrm{YSZ}[6,7,23,24,49]$. The scatter of the values for the $\mathrm{Ni}(\mathrm{O})-\mathrm{YSZ}$ composites can be due to compositional differences, differences in porosity, different measurement methods and measurement uncertainties, etc. However, the values in the oxidized state (NiO-YSZ) at room and operational temperature $\left(\sim 800^{\circ} \mathrm{C}\right)$ are comparable. In this work, the peaking of elastic modulus in oxidized state was 
not captured due to the limited number of measuring points around this temperature. But the here measured elastic moduli of NiO-YSZ ( 180 GPa) are consistent with most literature (150-180 GPa) [6, 7, $23,24,49]$. In reduced state (Ni-YSZ), the decrease of elastic modulus with increasing temperature is consistent with literature, but the reduction of around $61 \%$ seen here (from $\sim 78.3 \mathrm{GPa}$ at room temperature to $\sim 30.7 \mathrm{GPa}$ at $800{ }^{\circ} \mathrm{C}$ ) is larger than previous reports. Pihlatie et al showed a decrease of about $22 \%$ from room temperature $(72 \mathrm{GPa})$ to $800{ }^{\circ} \mathrm{C}(56 \mathrm{GPa})$ [23], while Biswas observed a decrease of about $40 \%$ from room temperature (75 GPa) to $800{ }^{\circ} \mathrm{C}$ (45 GPa) [24], and finally Sato et al reported a decrease of about $46 \%$ from room temperature (65 GPa) to $800{ }^{\circ} \mathrm{C}$ (35 GPa) [22]. These differences can be due to unwanted "side effects" of the measurement method such as general measuring error/inaccuracy, induced creep (particularly at high temperature) or crack propagation during deformation. In this work, bending lasts several seconds for each test, whereby the loading time is much longer than that in impulse excitation technique used in Refs. [23, 24]. Thus, the lower elastic modulus of Ni-YSZ at high temperature in this work is attributed to creep effects in the metallic Ni phase.

Strength drop at elevated temperature has previously been reported by Nakajo et al [7], Sukida, Sato, Hashida et al [21, 22] and Malzbender et al [15] for reduced Ni-YSZ anode materials and half-cells, which are consistent with our measurements. Nakajo et al [7] and Malzbender et al [15] however also reported a $13 \%$ and $27 \%$ decrease respectively in strength with increased temperature for the oxidized state. This was not observed in this work nor in Refs. [21,22], where less than 5\% decrease in strength was observed for NiO-YSZ from room temperature to $800^{\circ} \mathrm{C}$. For better comparison, those reported data in Refs. [7, 15, 22] are also listed in Tables 2 and 3. The strength values reported in Refs. [7, 15] are scaled to an effective volume of $1 \mathrm{~mm}^{3}$ to allow a proper comparison. The measured strength of $\mathrm{Ni}(\mathrm{O})$ YSZ in this work ( 400MPa for NiO-YSZ and 121-268 MPa for the reduced Ni-YSZ) are comparable with the scaled values from Refs. [7, 22], but much higher than the values reported in Ref. [15]. This is most likely due to the differences in porosity, type of YSZ (8YSZ vs $3 \mathrm{YZ}$ in this work) and residual stress in the half-cells tested in Ref. [15]. 
A large number of empirical and theoretical models have been proposed to express the dependence of the magnitude of elastic modulus and strength on the volume fraction of porosity, e.g. linear, exponential and non-linear correlations $[6,7,23,47,50]$. In the present work, the exponential relationships describing strength and elastic modulus as a function of porosity were used to fit the experimental data, as this has previously been successfully applied for SOFC anodes [6]:

$$
\begin{aligned}
& \sigma=\sigma_{0} \exp \left(-b_{\sigma} p\right) \\
& E=E_{0} \exp \left(-b_{E} p\right)
\end{aligned}
$$

Where $\sigma_{0}$ and $E_{0}$ are the zero porosity strength and elastic modulus respectively, $b_{\sigma}$ and $b_{E}$ are material constants reported to be 2.54 [6] and 2.48-2.70 [6, 7, 23, 49], respectively, for the NiO-YSZ composite. This exponential correlation has been shown to provide a good estimate of how the porosity influences the strength and elastic modulus. The exponential dependence of mechanical properties on porosity has also been reported in other materials, such as: GDC (gadolinia doped ceria) [51], $\mathrm{Ba}_{0.3} \mathrm{Co}_{4} \mathrm{Sb}_{12}$ [52], $\mathrm{PbTe}-\mathrm{PbS}$ thermoelectric composites [53], alumina and hydroxyapatite [54], etc. Moreover, similar " $b_{E}$ " values are obtained for a variety of materials as pointed out by Ren et al [54]. Fig. 7 shows a comparison of strength and elastic modulus (both at room temperature and $800{ }^{\circ} \mathrm{C}$ ) for the NiO-YSZ $(p=0.13)$ and Ni-YSZ $(p=0.36)$ measured in this work, with predicted values for NiO-YSZ according to the exponential correlations. According to the exponential correlations, the calculated strength and elastic modulus of fully dense NiO-YSZ $(p=0)$ are $589 \mathrm{MPa}$ and $260 \mathrm{GPa}$ respectively at room temperature.

At room temperature, the predicted elastic modulus and strength of a NiO-YSZ composite calculated for a porosity of 0.36 (corresponding to the observed one within the Ni-YSZ samples) is 98 GPa and $233 \mathrm{MPa}$. These values lie close to the ones observed for the Ni-YSZ (78.3 GPa for elastic modulus and $268 \mathrm{MPa}$ for strength). This indicates that at room temperature, the strength and elastic modulus decrease of the reduced Ni-YSZ anode supports compared to the as-prepared samples (NiO-YSZ) is primarily due to the increased porosity introduced by reduction. 
But at $800{ }^{\circ} \mathrm{C}$, the predicted strength $(224 \mathrm{MPa})$ and elastic modulus (97 GPa) of NiO-YSZ $(p=0.36)$ are much higher than the measured values for Ni-YSZ with the same porosity (strength: 121 $\mathrm{MPa}$; elastic modulus: $30.7 \mathrm{GPa}$ ). Thus, at high temperature the change of phase (from $\mathrm{NiO}$ to $\mathrm{Ni}$ ) plays a much more significant role. If we consider that the Ni in the Ni-YSZ $(p=0.36)$ composite does not contribute to the strength, the residual YSZ framework has a porosity of around 0.68 . It is interesting to note that a calculated strength and elastic modulus of a sample with a porosity of 0.68 would be $98 \mathrm{MPa}$ and $41 \mathrm{GPa}$ respectively, which actually lie fairly close to the measured values of the Ni-YSZ (strength: $121 \mathrm{MPa}$; elastic modulus: $30.7 \mathrm{GPa})$. This thus indicates that at high temperature $\left(800{ }^{\circ} \mathrm{C}\right)$, the further decrease of strength and elastic modulus in the reduced Ni-YSZ sample is due to that the Ni phase carries only a minor part of the load.

It is noteworthy that when comparing failure strains rather than failure stresses the picture changes. The failure strain of the Ni-YSZ $(0.34-0.44 \%)$ is higher than that of the NiO-YSZ $(0.22-0.24 \%)$, as shown in Fig. 6 (For strength it was opposite). The reason for this is most likely that in the reduced NiYSZ sample, the metal Ni phase, which has a high ductility will deform plastically under load especially at high temperature (where creep is active). Thus, the YSZ phase determines the strain at failure in the composite and the observed value for the Ni-YSZ in fact corresponds well to that of pure porous 3 YSZ [35]. The lower failure strain observed for the NiO-YSZ composite must thus be due to that the less compliant $\mathrm{NiO}$ limits of failure strain of the composite.

In order to get an insight into the evolution of fracture mechanisms for the $\mathrm{Ni}(\mathrm{O})-\mathrm{YSZ}$ anode supports with elevated temperatures, the fracture surfaces of the specimens after testing at different temperatures were investigated. As an example, Fig. 8 shows the SEM images of fracture surfaces tested at room temperature and $800{ }^{\circ} \mathrm{C}$, for both the reduced and unreduced specimens. It is seen that the specimens present distinctly different microstructure. The SEM images clearly show the faceted surfaces of fractured YSZ grains under all the testing conditions. As the grain size of YSZ is as fine as 200-300 $\mathrm{nm}$, the YSZ grains consequently failed in a predominantly intergranular manner after bending test no 

such fractured YSZ grains are indicated in the figure. While, fractures in the $\mathrm{Ni}(\mathrm{O})$ phase are mainly found in the unreduced specimens (Fig. 8a and c). It is clear that the big $\mathrm{NiO}$ grains in the unreduced specimens present a predominantly transgranular fracture after bending test. The fracture mode of the $\mathrm{NiO}$ grains remains unchanged with temperature (Fig. 8c). This is in good agreement with the observation that strength does not vary with temperature for the NiO-YSZ samples. In the reduced specimens, a few transgranular fractured $\mathrm{Ni}$ particles can be observed in the specimens tested at room temperature, as shown in Fig. 8b. But the Ni particles in the reduced specimens do not appear to be deformed at $800{ }^{\circ} \mathrm{C}$ (Fig. 8d). Additional fractography (Fig. 8e-f) close to the tensile surfaces reveals that the fracture in the studied $\mathrm{Ni}(\mathrm{O})$-YSZ specimens originates from near-surface flaws in most cases, e.g. agglomerates of YSZ, clusters of $\mathrm{Ni}(\mathrm{O})$ particles, or large cavities formed during casting, which is similar to the report by Radovic et al [6] and Biswas et al [17]. Therefore, controlling the flaw population generated during manufacturing processing was essential to ensure higher mechanical reliability of the cells.

Previous research on porous $\mathrm{Ni}(\mathrm{O})-\mathrm{YSZ}$ composites has indicated that the YSZ framework in the composite provides the main mechanical strength, both in reduced and unreduced samples, and both at room temperature and high temperature [5]. In addition to the YSZ phase, it is evident that the NiO grains also contribute significantly to the strength in the unreduced specimens both at room temperature and high temperature. While in reduced specimens, only a few transgranular fractured Ni particles can be observed in the test at room temperature, the Ni phase contributes much less to the strength of the structure at high temperature, which is in good agreement with the relatively fast unloading of the $\mathrm{Ni}$ phase through creep [55]. As well in good agreement with our analysis in Fig. 7, these results of fracture topography confirm that at room temperature, the degradation of strength and elastic modulus of the reduced Ni-YSZ sample compared to the unreduced one is primarily due to the increased porosity introduced by the reduction; but at elevated temperatures, the further degradation of strength and elastic modulus in the reduced Ni-YSZ is due to a diminished contribution of the Ni phase in carrying load for 
the brittle deformation. On the other hand the reduction leads to a significant increase in failure strain of the anode support by a factor of $1.5-2$, which is beneficial for the operation of a SOFC. This can be explained by that the rigid brittle $\mathrm{NiO}$ phase is replaced by ductile $\mathrm{Ni}$.

\section{Conclusions}

In this work, the influence of operational conditions, including reduction temperatures and testing temperatures, on the strength distribution and elastic moduli of Ni-YSZ and NiO-YSZ Solid Oxide Fuel Cell anode supports was investigated. The statistical distribution of strength was determined from a large number of samples $(\sim 30)$ at each condition for high statistical validity. The high number of experiments was achieved by use of a novel method, where up to 16 samples can be tested at one heat up.

The influence of four reduction temperatures at $700{ }^{\circ} \mathrm{C}$ in $8 \mathrm{~h}, 800{ }^{\circ} \mathrm{C}$ in $6 \mathrm{~h}, 900{ }^{\circ} \mathrm{C}$ in $4 \mathrm{~h}$ and $1000{ }^{\circ} \mathrm{C}$ in $2 \mathrm{~h}$ was studied. The $\mathrm{NiO}$ could be reduced completely at each of the investigated conditions. It was found that mass diffusion among the newly formed $\mathrm{Ni}$ particles is promoted as temperature elevates, which results in larger pores at higher reduction temperatures. This yielded a tendency of a slightly improved strength $(\sim 12 \%)$ and enhanced elastic moduli at elevated reduction temperatures in spite of the increasing mean pore size. This could be due to the promoted mass diffusion among Ni particles at higher temperature, resulting in some healing of the defects or flaws within the material. We suggested the hypothesis for the strength increase that the compressive thermal residual stress accumulated in the YSZ particles is also beneficial for the improved strength when the samples were reduced at temperatures higher than testing temperature. As another indicator for the cells mechanical performance, the failure strain of Ni-YSZ anode support was determined, it achieves a maximum at a reduction temperature of $900{ }^{\circ} \mathrm{C}$.

Further studies were conducted to investigate the strength and elastic moduli dependency on temperature for both the unreduced and reduced $\mathrm{Ni}(\mathrm{O})-\mathrm{YSZ}$ anode supports with a fixed reduction 
temperature at $800{ }^{\circ} \mathrm{C}$. Considering measurement uncertainty, the respective Weibull moduli remain constant at different temperatures for both the reduced and un-reduced states. Thus new defect types do not seem to appear with temperature variation (e.g. from internal residual stress release between the phases). Therefore for this system, it is acceptable to let the number of samples for assessment of high temperature properties be dictated by the needs for assessment of the Weibull strength rather than for the Weibull modulus.

With increasing temperature, the strength and elastic moduli of the reduced Ni-YSZ specimens drop almost linearly from respectively $\sim 268 \mathrm{MPa}$ and $\sim 78.3 \mathrm{GPa}$ at room temperature to $\sim 121 \mathrm{MPa}$ and $\sim 30.7 \mathrm{GPa}$ at $800{ }^{\circ} \mathrm{C}$ respectively. In contrast, almost no drop of strength and elastic moduli is observed in unreduced NiO-YSZ anode supports. The strength and elastic moduli of the unreduced NiO-YSZ anode supports ( $400 \mathrm{MPa}$ and $\sim 180 \mathrm{GPa}$ respectively) remain almost constant over the investigated temperature range from room temperature to $800{ }^{\circ} \mathrm{C}$. Compared to the NiO-YSZ specimens, a significantly lower strength and elastic modulus of the reduced Ni-YSZ is observed over the investigated temperature range.

From the results it is deduced that the strength and elastic modulus degradation at room temperature for the reduced Ni-YSZ is primarily an effect of the increased porosity (increased from $13 \%$ to $36 \%$ ) introduced by reduction independent of the apparent material phases; but at elevated temperatures, the further strength reduction in the Ni-YSZ is due to a diminished contribution of the Ni phase to the strength of the composite.

Looking instead at the failure strains; these are observed to increase significantly between the samples in oxidized state and the ones in reduced state. The failure strain in the Ni-YSZ was observed to lie between 0.34 and $0.44 \%$. The strain of failure is $48 \%$ and $83 \%$ higher for the samples in reduced state than that for the as-prepared ones at room temperature and $900{ }^{\circ} \mathrm{C}$ respectively. The high failure strain of the Ni-YSZ $(0.34-0.44 \%)$ is due to compliant Ni phase, and thus that the failure strain is determined by 
the YSZ phase. Indeed the failure strain of the Ni-YSZ compares well with that of pure YSZ (3YSZ). The failure strain of the NiO-YSZ $(0.22-0.24 \%)$ is however significantly lower and it must thus be due to the less compliant NiO-phase. It should be noted that the failure strain is in many cases more important for the mechanical performance of the SOFC than the strength, as the mechanical load is mainly determined by thermal expansions. Hence in a simplified picture of the strength of the Ni-YSZ and NiO-YSZ, one may state that Ni-YSZ behaves like porous YSZ, particularly at high temperature where Ni is "soft"; whereas the NiO-YSZ behaves like a composite of two brittle phases the strength and stain at failure being dictated by the weaker of the two phases (the $\mathrm{NiO}$ ).

\section{Acknowledgments:}

The research leading to these results has received funding from the European Union's Seventh Framework Programme (FP7/2007-2013) for the Fuel Cells and Hydrogen Joint Technology Initiative under grant agreement $\mathrm{n}^{\circ}$ 325278, Energinet.dk under the Public Service Obligation, ForskEL contract 2014-1-12236 and from Danish Council for Independent Research (DFF) on Technology and Production Sciences (FTP) under grant contract DFF - 1337-00146. 


\section{References:}

[1] N. Minh, J. Am. Ceram. Soc. 3 (1993) 563-588.

[2] S.C. Singhal, K. Kendall, High-temperature solid oxide fuel cells: Fundamentals, design and applications. Elsevier Ltd., Oxford, UK, 2003.

[3] B.C.H. Steele, A. Heinzel, Nature 414 (2001) 345-352.

[4] A. Faes, A. Hessler-Wyser, A. Zryd, J. Van Herle, Membranes 2 (2012) 585-664.

[5] Y. Wang, M.E. Walter, K. Sabolsky, M.M. Seabaugh, Solid State Ionics 177 (2006) 1517-1527.

[6] M. Radovic, E. Lara-Curzio, Acta Mater. 52 (2004) 5747-5756.

[7] A. Nakajo, J. Kuebler, A. Faes, U.F. Vogt, H.J. Schindler, L. Chiang, S. Modena, J. Van Herle, T. Hocker, Ceram. Int. 38 (2012) 3907-3927.

[8] B. Charlas, H.L. Frandsen, K. Brodersen, P.V. Hendriksen, M. Chen, J. Power Sources 288 (2015) $243-252$.

[9] W. Weibull, Ingenioersvetens Kapskad Handl 151 (1939) 1-45.

[10] W. Weibull, J. Appl. Mech. 18 (1951) 293-297.

[11] J. Malzbender, R.W. Steinbrech, J. Eur. Ceram. Soc. 28 (2008) 247-252.

[12] H.L. Frandsen, T. Ramos, A. Faes, M. Pihlatie, K. Brodersen, J. Eur. Ceram. Soc. 32 (2012) 10411052.

[13] H.L. Frandsen, D.J. Curran, S. Rasmussen, P.V. Hendriksen, J. Power Sources 258 (2014) 195-203.

[14] A. Khalili, K. Kromp, J. Mater. Sci. 26 (1991) 6741-6752.

[15] J. Malzbender, R. Steinbrech, L. Singheiser, Failure probability of solid oxide fuel cells, in: Ceramic Engineering and Science Proceedings, vol. 26, American Ceramic Society, pp. 293-298, 2008.

[16] A. Faes, H.L. Frandsen, A. Kaiser, M. Pihlatie, Fuel Cells 11(2010) 682-689.

[17] S. Biswas, T. Nithyanantham, S.N. Thangavel, S. Bandopadhyay, Ceram. Int. 39 (2013) 3103-3111.

[18] A. Faes, H.L. Frandsen, M. Pihlatie, A. Kaiser, D.R. Goldstein, J. Fuel Cell Sci. Technol. 7 (2010) 051011 .

[19] S. Goutianos, H.L. Frandsen, B.F. Sorensen, J. Eur. Ceram. Soc. 30(2010) 3173-3179. 
[20] F. Fleischhauer, R. Bermejo, R. Danzer, A. Mai, T. Graule, J. Kuebler, J. Power Sources 273(2015) $237-243$.

[21] S. Sukino, S. Watanabe, K. Sato, T. Kawada, J. Miuzusaki, T. Hashida, ECS Trans. 35 (2011) $1473-1482$.

[22] K. Sato, T. Miyasaka, S. Watanabe, T. Hashida, ECS Trans. 57 (2013) 753-762.

[23] M. Pihlatie, A. Kaiser, M. Mogensen, J. Eur. Ceram. Soc. 29 (2009) 1657-1664.

[24] S. Biswas, T. Nithyanantham, N.T. Saraswathi, S. Bandopadhyay, J. Mater. Sci. 44 (2009) 778-785.

[25] A. Hagen, R. Barfod, P.V. Hendriksen, Y.L. Liu, S. Ramousse, J. Electrochem. Soc. 153 (2006) A1165eA1171.

[26] T. Klemenso, E. Lund, B.F. Sorensen, J. Am. Ceram. Soc. 90 (2007) 1827-1835.

[27] http://rsbweb.nih.gov/ij/.

[28] H.L. Frandsen , M. Makowska, F. Greco1, D.W. Ni, D.J. Curran, M. Strobl, L.T. Kuhn, P.V. Hendriksen, Accelerated creep in solid oxide fuel cell Ni-YSZ anode supports during reduction, J. Power Sources, submitted, 2015.

[29] W. Weibull, The phenomenon of rupture in solids. Generalstabena Litografiska Anstalts Forlag, 1939.

[30] J. Laurencin, G. Delette, M. Dupeux, J. Eur. Ceram. Soc. 28 (2008) 1-13.

[31] H.L. Frandsen, Mech. Mater. 73 (2014) 28-37.

[32] G.D. Quinn, J. Am. Ceram. Soc. 86 (2003) 475-479.

[33] M. Radovic, E. Lara-Curzio, L. Riester, Mater. Sci. Eng. A 368 (2004) 56-70.

[34] G. Pecanac, S. Baumann, J. Malzbender, J. Membr. Sci. 385-386(2011) 263-268.

[35] Z.Y. Deng, J.F. Yang, Y. Beppu, M. Ando, T. Ohji, J. Am. Ceram. Soc. 85 (2002) 1961-1965.

[36] A.A. Griffith, Phil. Trans. Roy. Soc. 221 (1921) 163-198.

[37] J.J. Marigo, L. Truskinovky, Continuum Mech. Thermodyn. 16 (2004) 391-409.

[38] D.W. Ni, J.X. Liu, G.J. Zhang, J. Eur. Ceram. Soc. 32 (2012) 3627-3635.

[39] H.W. Kim, H.E. Kim, J. Am. Ceram. Soc. 81 (1998) 2130-2134.

[40] H.W. Kim, H.E. Kim, H. Song, J. Ha, J. Am. Ceram. Soc. 82 (1999) 1601-1604. 
[41] P. Hidnert, J. Res. Nat. Bur. Stand. 58 (1957) 89-92.

[42] M.R. Ardigo, A. Perron, L. Combemale, O. Heintz, G. Caboche, S. Chevalier, J. Power Sources 196 (2011) 2037-2045.

[43]R. Danzer, T. Lube, P. Supancic, Zeitschrift Fur Metallkunde 92 (2001) 773-783.

[44] K. Kwok, L. Kiesel, H.L. Frandsen, M. Søgaard, P.V. Hendriksen, J. Eur. Ceram. Soc. 34 (2014) $1423-1432$.

[45] Standard practice for reporting uniaxial strength data and estimating Weibull distribution parameters for advanced ceramics, ASTM _ C1239-07.

[46] D. Kalish, E.V. Clougherty, K. Kreder, J. Am. Ceram. Soc. 52 (1969) 30-36.

[47] Y.W. Kim, Y.S. Chun, T. Nishimura, M. Mitomo, Y.H. Lee, Acta Mater. 55 (2007) 727-736.

[48] http://www.engineeringtoolbox.com/young-modulus-d 773.html.

[49] A. Selcuk, A. Atkinson, J. Eur. Ceram. Soc. 17 (1997) 1523-1532.

[50] R.W. Rice, Porosity of ceramics. New York: Marcel Dekker, Inc., 1998.

[51] X. Fan, E.D. Case, Q. Yang, J.D. Nicholas, Ceram. Int. 39 (2013) 6877-6886.

[52] R.D. Schmidt, E.D. Case, Z. Lobo, T.R. Thompson, J.S. Sakamoto, X.Y. Zhou, C. Uher, J. Mater. Sci. 49 (2014) 7192-7212.

[53] J.E. Ni, E.D. Case, R.D. Schmidt, C.I Wu, T.P. Hogan, R.M. Trejo, E. Lara-Curzio, M.G. Kanatzidis, Philos. Mag. 93 (2013) 4412-4439.

[54] F. Ren, E.D. Case, A. Morrison, M. Tafesse, M.J. Baumann, Philos. Mag. 89 (2009) 1163-1182.

[55] K. Kwok, P.S. Jørgensen, H.L. Frandsen, J. Am. Ceram. Soc. 98(2015) 2873-2880. 


\section{Figure and Table Captions:}

Fig. 1 Four point bending configuration (a), first principal stress field at the bottom of the sample evaluated by finite element simulations (FEM) (b) and normalized principal stress variation across the width at the central bottom of the sample (c).

Fig. 2 (a) Weibull plots showing the distribution of strength for Ni-YSZ anode supports reduced at different conditions; (b) The variation of Weibull strengths and failure strains as a function of reduction temperature for the reduced Ni-YSZ anode supports. All the samples were tested at $800{ }^{\circ} \mathrm{C}$.

Fig. 3 SEM images of polished cross sections for the Ni-YSZ anode supports reduced at different conditions, together with the unreduced NiO-YSZ.

Fig. 4 Pore size distribution of the Ni-YSZ anode supports reduced at different conditions.

Fig. 5 Weibull plots showing the distribution of strength for the reduced (a) and unreduced (b) $\mathrm{Ni}(\mathrm{O})-\mathrm{YSZ}$ anode supports over the temperature range from room temperature to $800{ }^{\circ} \mathrm{C}$. All the $\mathrm{Ni}-$ YSZ specimens showing in Fig. 5 (a) were reduced at $800{ }^{\circ} \mathrm{C}$ in $6 \mathrm{~h}$.

Fig. 6 The change of elastic moduli, Weibull strengths and failure strains as a function of testing temperature for the reduced and unreduced $\mathrm{Ni}(\mathrm{O})-\mathrm{YSZ}$ anode supports.

Fig. 7 Comparison of strength (a) and elastic modulus (b) (both at room temperature and $800{ }^{\circ} \mathrm{C}$ ) of the NiO-YSZ $(p=0.13)$ and Ni-YSZ $(p=0.36)$ measured in this work, with predicted values of NiO-YSZ according to the exponential correlations. The artificial sample NiO-YSZ $(p=0.68)$ is corresponding to the YSZ framework in the measured Ni-YSZ sample $(p=0.36)$.

Fig. 8 SEM images of fracture surfaces for both the unreduced (a, c) and reduced (b, d) Ni(O)-YSZ specimens after bending testing at room temperature and $800^{\circ} \mathrm{C} ;(\mathrm{e}, \mathrm{f})$ show typical failure origins closer to the tensile surface.

Table 1 Weibull strength, Weibull modulus, effective volume, elastic modulus and porosity for Ni-YSZ anode support specimens reduced at different conditions. $\sigma_{0}$ ' denotes the Weibull strength scaled to an effective volume of $1 \mathrm{~mm}^{3}$. All the bending tests were performed at $800{ }^{\circ} \mathrm{C}$. 
Table 2 Weibull strength, Weibull modulus, effective volume, elastic modulus and porosity for reduced Ni-YSZ anode support specimens tested at different temperatures. $\sigma_{0}$ ' denotes the Weibull strength scaled to an effective volume of $1 \mathrm{~mm}^{3}$, using an average Weibull modulus for the samples tested at different temperatures. All the specimens were reduced at $800{ }^{\circ} \mathrm{C}(6 \mathrm{~h})$.

Table 3 Weibull strength, Weibull modulus, effective volume, elastic modulus and porosity for unreduced NiO-YSZ anode support specimens tested at different temperatures. $\sigma_{0}$ ' denotes the Weibull strength scaled to an effective volume of $1 \mathrm{~mm}^{3}$, using an average Weibull modulus for the samples tested at different temperatures. 
Table 1 Weibull strength, Weibull modulus, effective volume, elastic modulus and porosity for Ni-YSZ anode support specimens reduced at different conditions. $\sigma_{0}{ }^{\prime}$ denotes the Weibull strength scaled to an effective volume of $1 \mathrm{~mm}^{3}$. All the bending tests were performed at $800{ }^{\circ} \mathrm{C}$.

\begin{tabular}{cccccccc}
\hline Reduction temp. & $\boldsymbol{\sigma}_{\mathbf{0}}(\mathbf{M P a}) *$ & $\boldsymbol{m}{ }^{*}$ & $\boldsymbol{V}_{\text {eff }}\left(\mathbf{m m}^{\mathbf{3}}\right)$ & $\boldsymbol{E}(\mathbf{G P a})^{\#}$ & Porosity & $\boldsymbol{\sigma}_{\mathbf{0}}{ }^{\prime}(\mathbf{M P a})$ & $\boldsymbol{\sigma}_{\mathbf{0}}{ }^{\prime} / \mathbf{E}(\boldsymbol{\%})$ \\
\hline $\mathbf{7 0 0}^{\circ} \mathbf{C}$ & $127(124-131)$ & $12.2(8.9-16.3)$ & 0.40 & $31.5 \pm 3.1$ & 0.36 & 121 & $0.38(0.34-0.42)$ \\
$\mathbf{8 0 0}{ }^{\circ} \mathbf{C}$ & $124(121-127)$ & $14.5(10.6-19.3)$ & 0.73 & $30.7 \pm 1.4$ & 0.35 & 121 & $0.39(0.36-0.42)$ \\
$\mathbf{9 0 0}^{\circ} \mathbf{C}$ & $128(125-131)$ & $13.5(9.8-18.0)$ & 0.79 & $31.3 \pm 2.3$ & 0.36 & 126 & $0.40(0.36-0.44)$ \\
$\mathbf{1 0 0 0}^{\circ} \mathbf{C}$ & $140(138-143)$ & $16.7(12.1-22.3)$ & 0.56 & $37.8 \pm 3.2$ & 0.36 & 136 & $0.36(0.33-0.40)$ \\
$\mathbf{6 0 0}^{\circ} \mathbf{C}[18]$ & 318 & 10.0 & - & - & $\sim 0.30$ & - & - \\
$\mathbf{1 0 0 0}^{\circ} \mathbf{C}[18]$ & 361 & 11.0 & - & - & $\sim 0.30$ & - & - \\
\hline
\end{tabular}

The materials tested in Ref. [18] are Ni-YSZ/8YSZ.

* Inside brackets is the $90 \%$ confidence interval.

\# (Average value) \pm (standard deviation). 
Table 2 Weibull strength, Weibull modulus, effective volume, elastic modulus and porosity for reduced $\mathrm{Ni}-$ YSZ anode support specimens tested at different temperatures. $\sigma_{0}$ ' denotes the Weibull strength scaled to an effective volume of $1 \mathrm{~mm}^{3}$, using an average Weibull modulus for the samples tested at different temperatures. All the specimens were reduced at $800{ }^{\circ} \mathrm{C}(6 \mathrm{~h})$.

\begin{tabular}{|c|c|c|c|c|c|c|c|c|}
\hline Test temp. & $\sigma_{0}(\mathbf{M P a}) *$ & $m *$ & $V_{e f f}\left(\mathrm{~mm}^{3}\right)$ & $E(\mathbf{G P a})^{\#}$ & Porosity & $\sigma_{0}^{\prime}(\mathbf{M P a})$ & $\sigma_{0}{ }^{\prime} / \mathrm{E}(\%) *$ & $\left(\sigma_{0}{ }^{\prime}\right)^{2} / \mathbf{E}(\mathbf{M P a})$ \\
\hline $25^{\circ} \mathrm{C}$ & $272(266-278)$ & $14.9(10.8-19.8)$ & 0.80 & $78.3 \pm 3.4$ & 0.36 & 268 & $0.34(0.32-0.36)$ & 0.92 \\
\hline $400^{\circ} \mathrm{C}$ & $236(229-242)$ & $11.7(8.5-15.7)$ & 1.08 & $60.1 \pm 6.1$ & 0.36 & 237 & $0.39(0.35-0.43)$ & 0.93 \\
\hline $600^{\circ} \mathrm{C}$ & $183(178-187)$ & $13.5(9.9-17.9)$ & 0.86 & $40.9 \pm 2.8$ & 0.36 & 180 & $0.44(0.40-0.48)$ & 0.79 \\
\hline $800^{\circ} \mathrm{C}$ & $124(121-127)$ & $14.5(10.5-19.3)$ & 0.73 & $30.7 \pm 1.4$ & 0.35 & 121 & $0.39(0.36-0.42)$ & 0.48 \\
\hline $25^{\circ} \mathbf{C}[15]$ & 84 & 13.2 & 9.73 & - & - & 110 & - & - \\
\hline $\mathbf{8 0 0}^{\circ} \mathbf{C}[15]$ & 67 & 13.2 & 9.73 & - & - & 87 & - & - \\
\hline $\mathbf{2 5}{ }^{\circ} \mathbf{C}[22]$ & 230 & - & - & 65 & $\sim 0.35$ & - & 0.35 & - \\
\hline $\mathbf{8 0 0}^{\circ} \mathbf{C}$ [22] & 90 & - & - & 35 & $\sim 0.35$ & - & 0.28 & - \\
\hline
\end{tabular}

The materials tested in Refs. [15] and [22] are Ni-YSZ/8YSZ and Ni-8YSZ respectively.

* Inside brackets is the $90 \%$ confidence interval.

\# (Average value) \pm (standard deviation). 
Table 3 Weibull strength, Weibull modulus, effective volume, elastic modulus and porosity for unreduced NiO-YSZ anode support specimens tested at different temperatures. $\sigma_{0}{ }^{\prime}$ denotes the Weibull strength scaled to an effective volume of $1 \mathrm{~mm}^{3}$, using an average Weibull modulus for the samples tested at different temperatures.

\begin{tabular}{|c|c|c|c|c|c|c|c|}
\hline Test temp. & $\sigma_{0}(\mathrm{MPa}) *$ & $m *$ & $V_{e f f}\left(\mathbf{m m}^{3}\right)$ & $E(\mathbf{G P a})^{\#}$ & Porosity & $\sigma_{0},(\mathbf{M P a})$ & $\sigma_{0} / \mathbf{E}(\%) *$ \\
\hline $25^{\circ} \mathrm{C}$ & $412(400-424)$ & $10.9(7.9-14.5)$ & 1.29 & $183 \pm 10.9$ & 0.13 & 420 & $0.23(0.21-0.25)$ \\
\hline $200^{\circ} \mathrm{C}$ & $411(403-419)$ & $16.1(11.6-21.5)$ & 0.72 & $176 \pm 15.9$ & 0.13 & 401 & $0.23(0.20-0.25)$ \\
\hline $400^{\circ} \mathrm{C}$ & $407(398-416)$ & $15.1(11.0-20.1)$ & 0.83 & $187 \pm 12.8$ & 0.13 & 401 & $0.22(0.20-0.24)$ \\
\hline $600{ }^{\circ} \mathrm{C}$ & $409(399-419)$ & $13.3(9.7-17.9)$ & 0.99 & $181 \pm 15.8$ & 0.13 & 408 & $0.24(0.21-0.27)$ \\
\hline $800^{\circ} \mathrm{C}$ & $400(385-414)$ & $11.7(9.4-14.3)$ & 1.18 & $181 \pm 13.1$ & 0.13 & 405 & $0.24(0.21-0.26)$ \\
\hline $25^{\circ} \mathrm{C}[7]$ & $290(277-304)$ & $6.8(5.4-8.6)$ & 10.11 & 172 & - & 408 & 0.17 \\
\hline $\mathbf{8 0 0}^{\circ} \mathbf{C}$ [7] & $253(242-266)$ & $6.6(5.2-8.4)$ & 10.69 & 169 & - & 362 & 0.15 \\
\hline $\mathbf{2 5}^{\circ} \mathbf{C}[15]$ & 115 & 13.2 & 9.73 & - & - & 150 & - \\
\hline $\mathbf{8 0 0}^{\circ} \mathbf{C}[15]$ & 84 & 13.2 & 9.73 & - & - & 110 & - \\
\hline $\mathbf{2 5}^{\circ} \mathbf{C}[22]$ & 430 & - & - & 140 & $\sim 0.12$ & - & 0.31 \\
\hline $\mathbf{8 0 0}^{\circ} \mathbf{C}[22]$ & 410 & - & - & 165 & $\sim 0.11$ & - & 0.25 \\
\hline
\end{tabular}

The materials tested in Refs. [7], [15] and [22] are NiO-8YSZ, NiO-YSZ/8YSZ and NiO-8YSZ respectively.

* Inside brackets is the $90 \%$ confidence interval.

\# (Average value) \pm (standard deviation). 
(a)

(b)
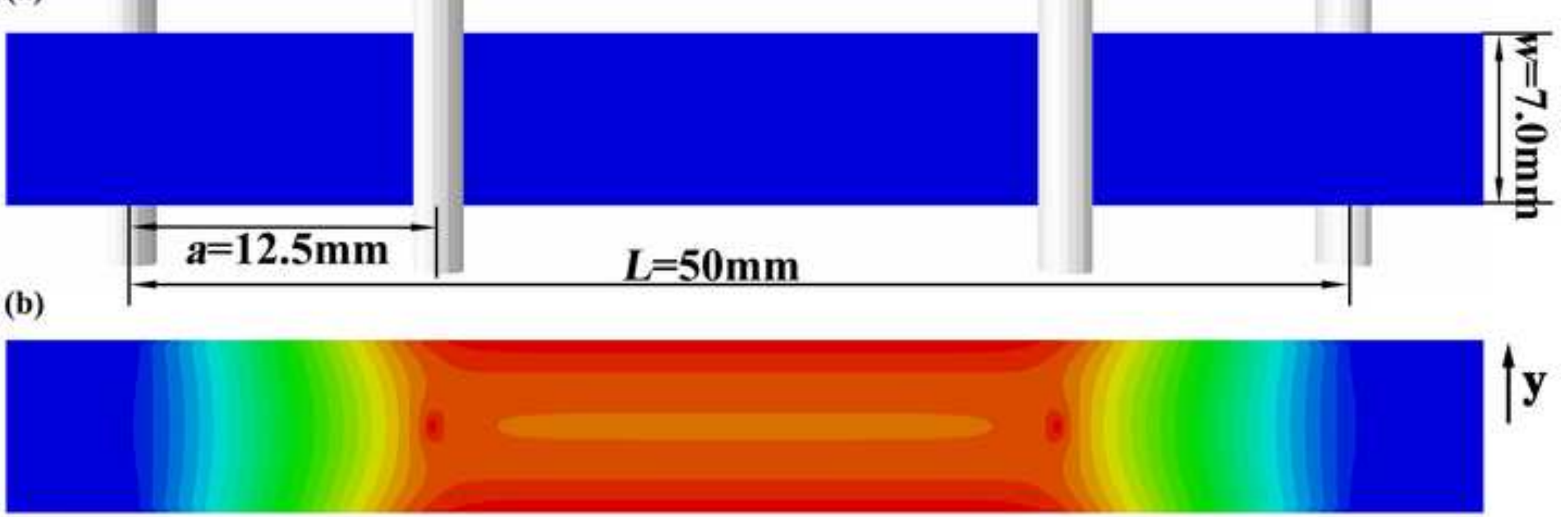

(c)

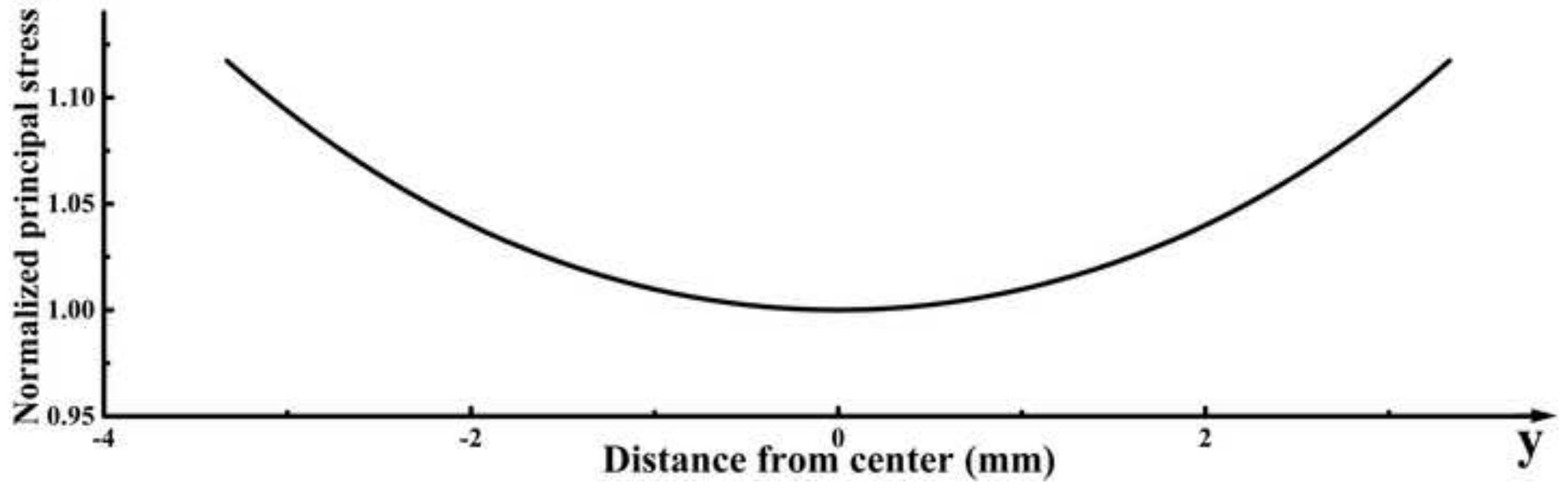


Click here to download high resolution image
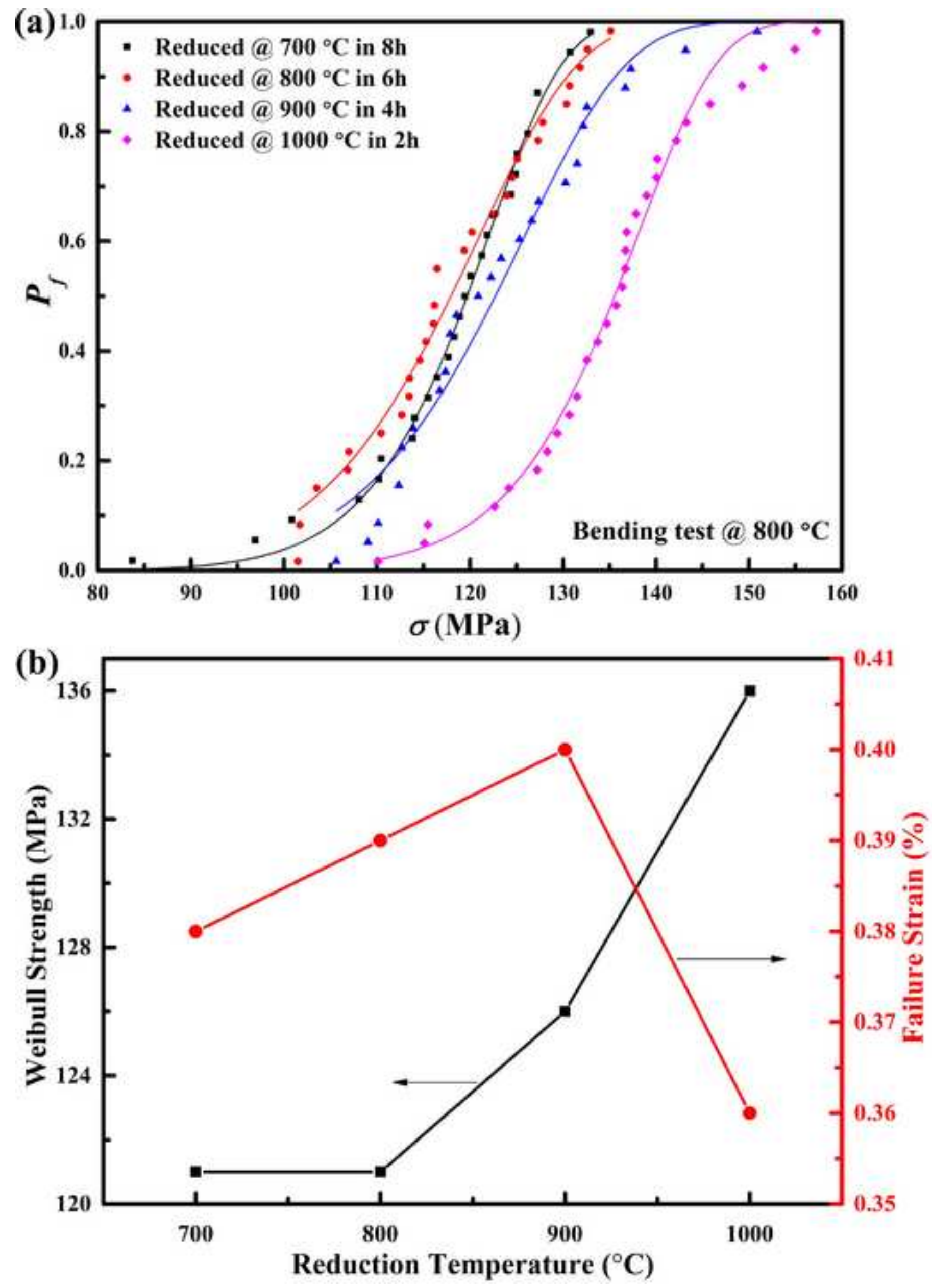
Click here to download high resolution image
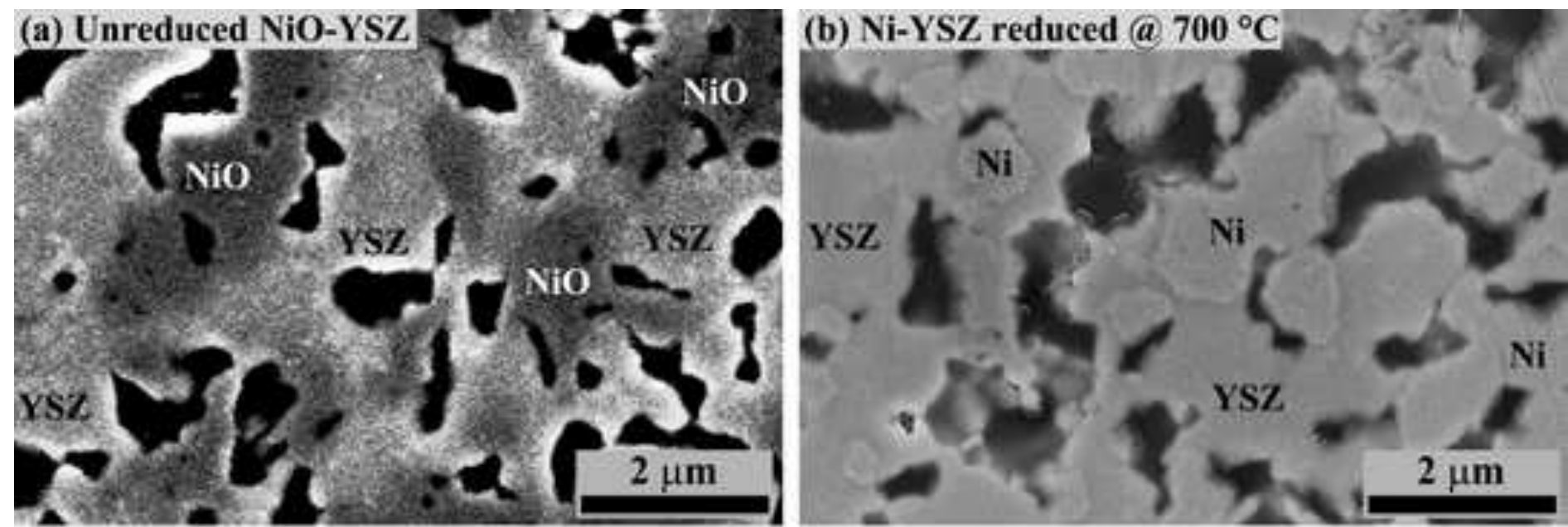

(c) Ni-YSZ reduced @ $800^{\circ} \mathrm{C}$
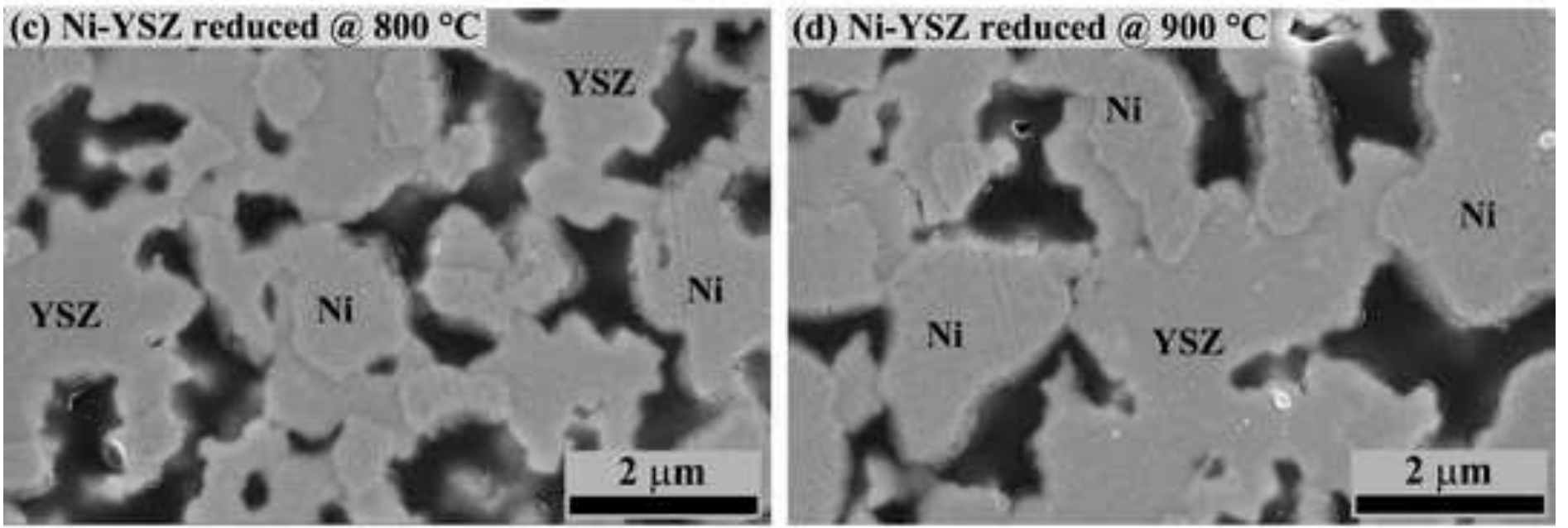

(e) Ni-YSZ reduced $@ 1000^{\circ} \mathrm{C} \quad \mathrm{I}, 4$

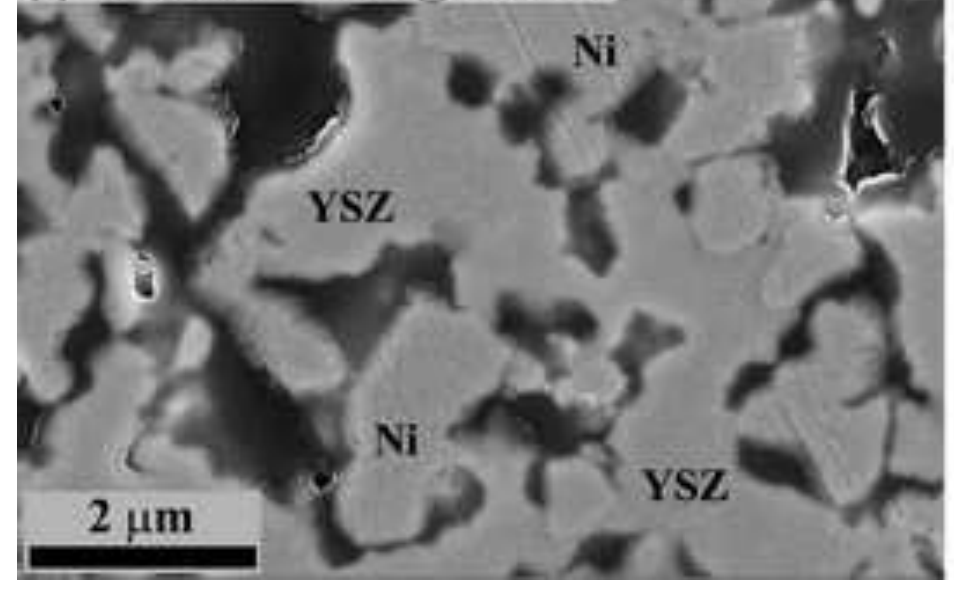


Click here to download high resolution image

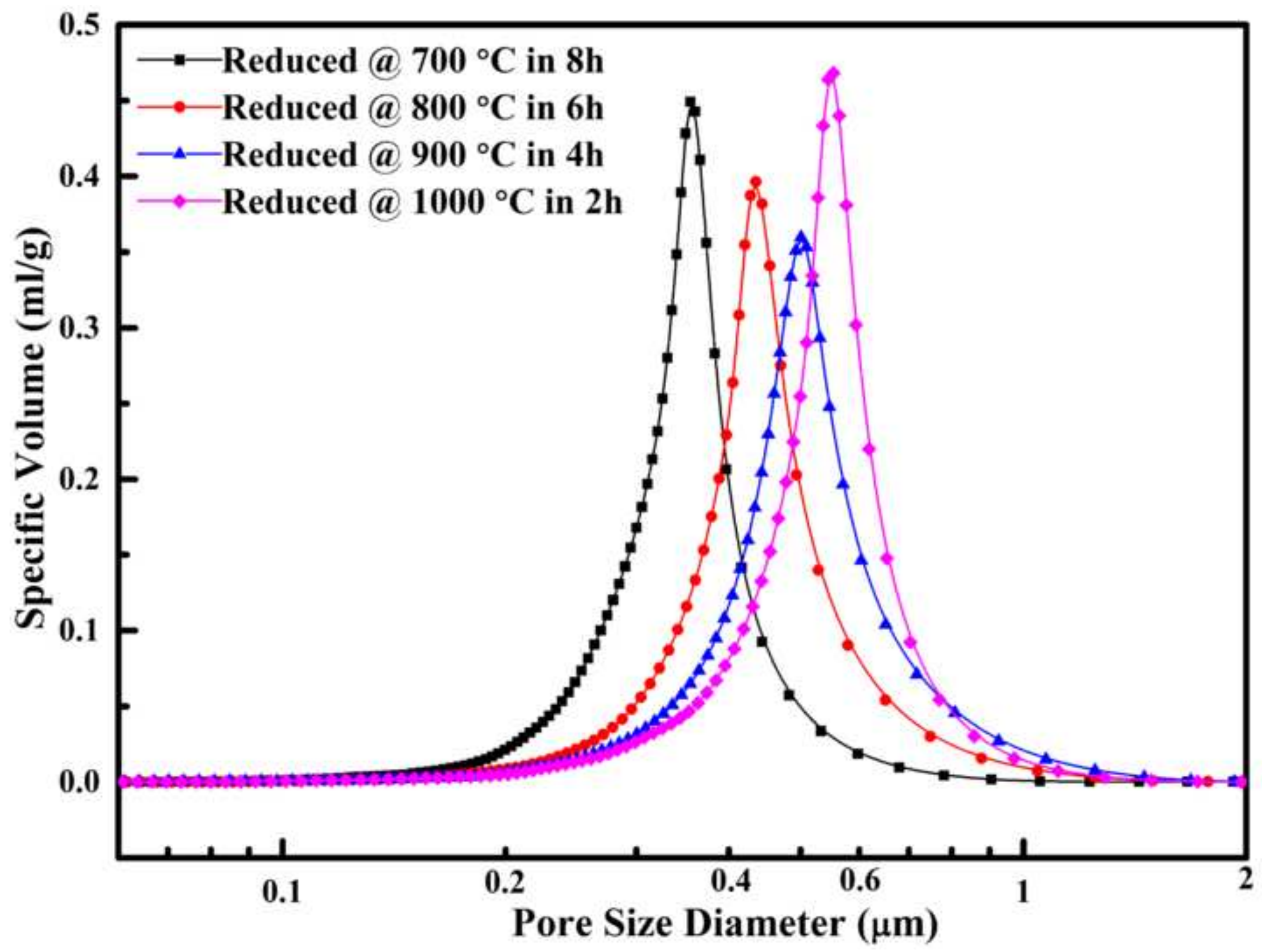



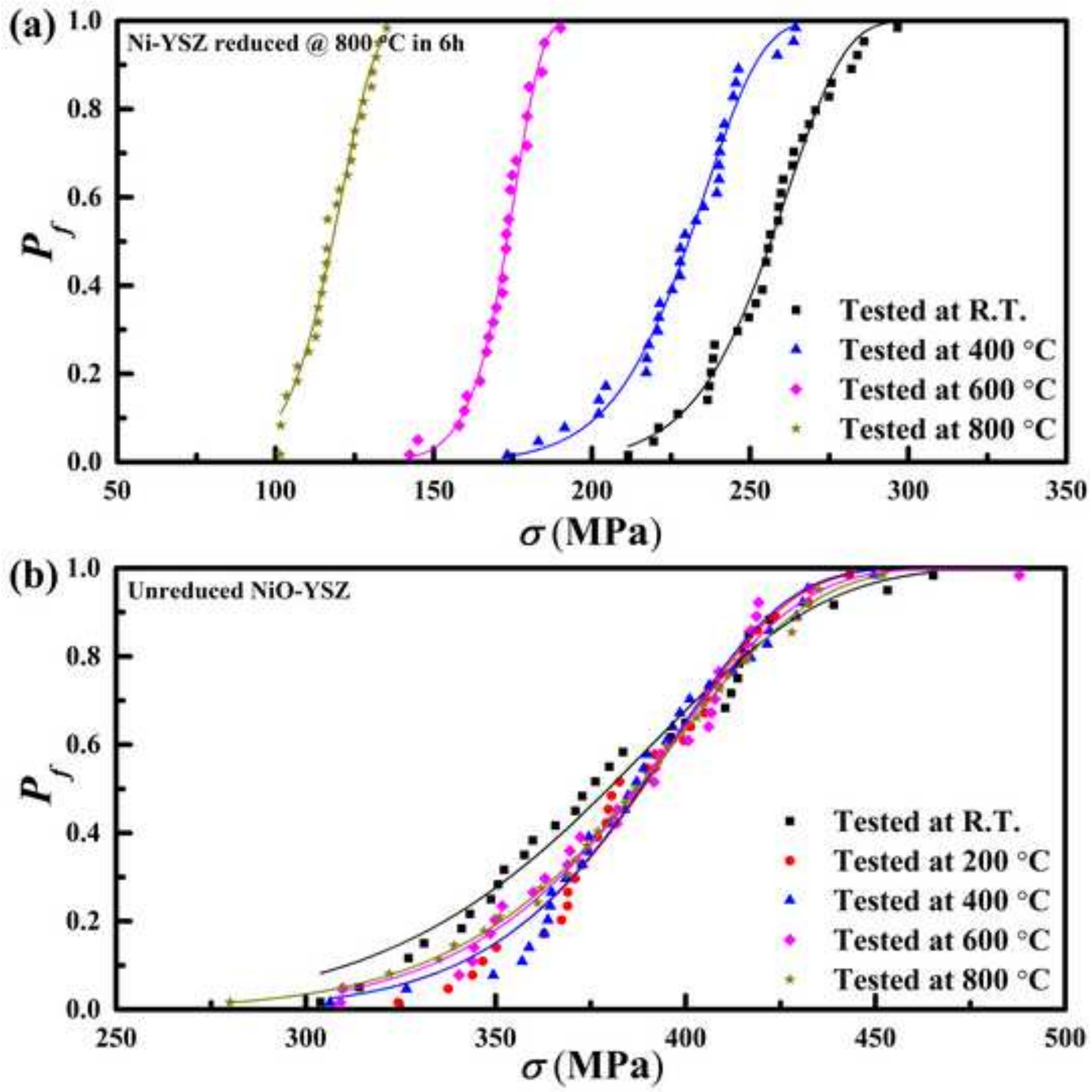
Figure 6

Click here to download high resolution image

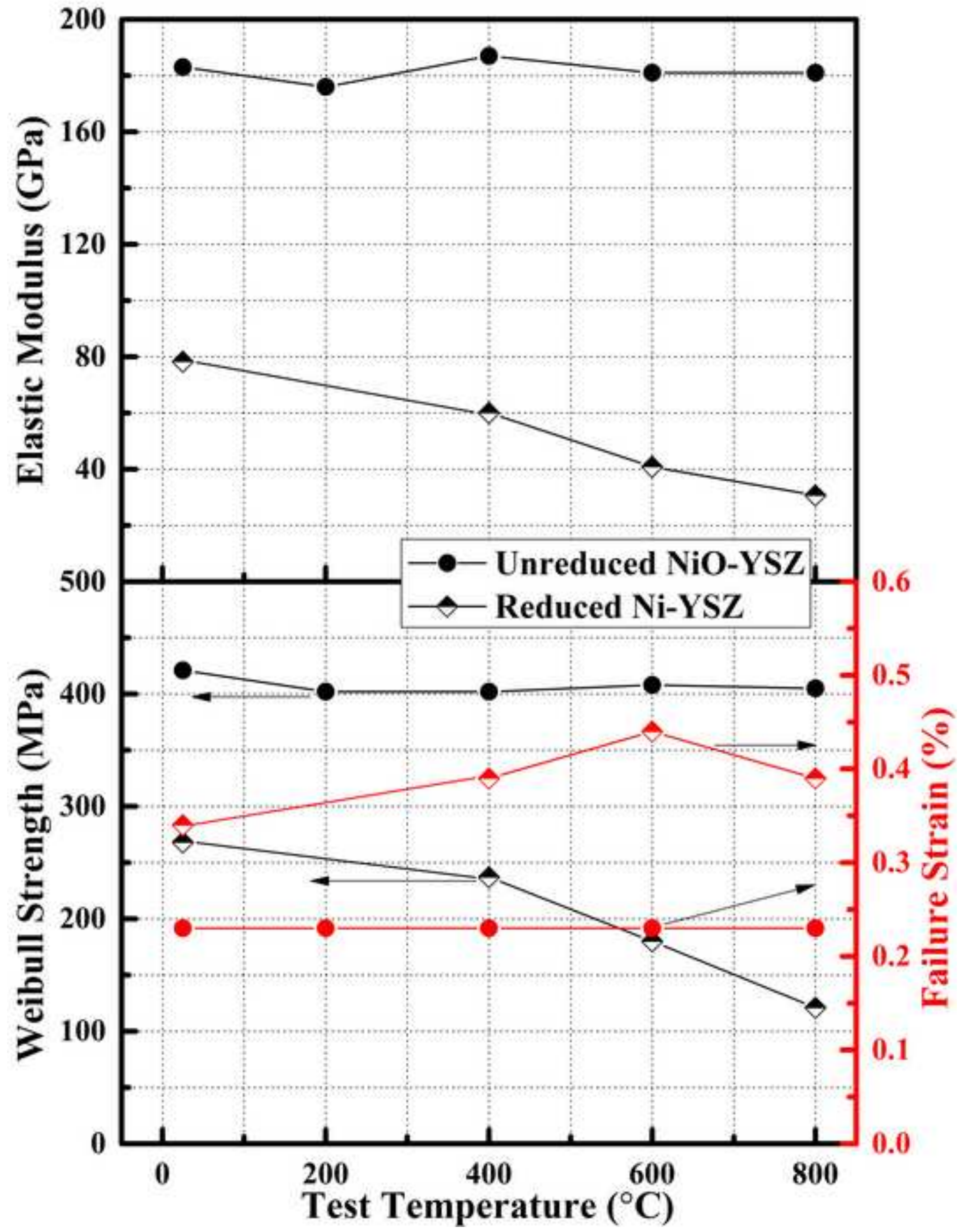



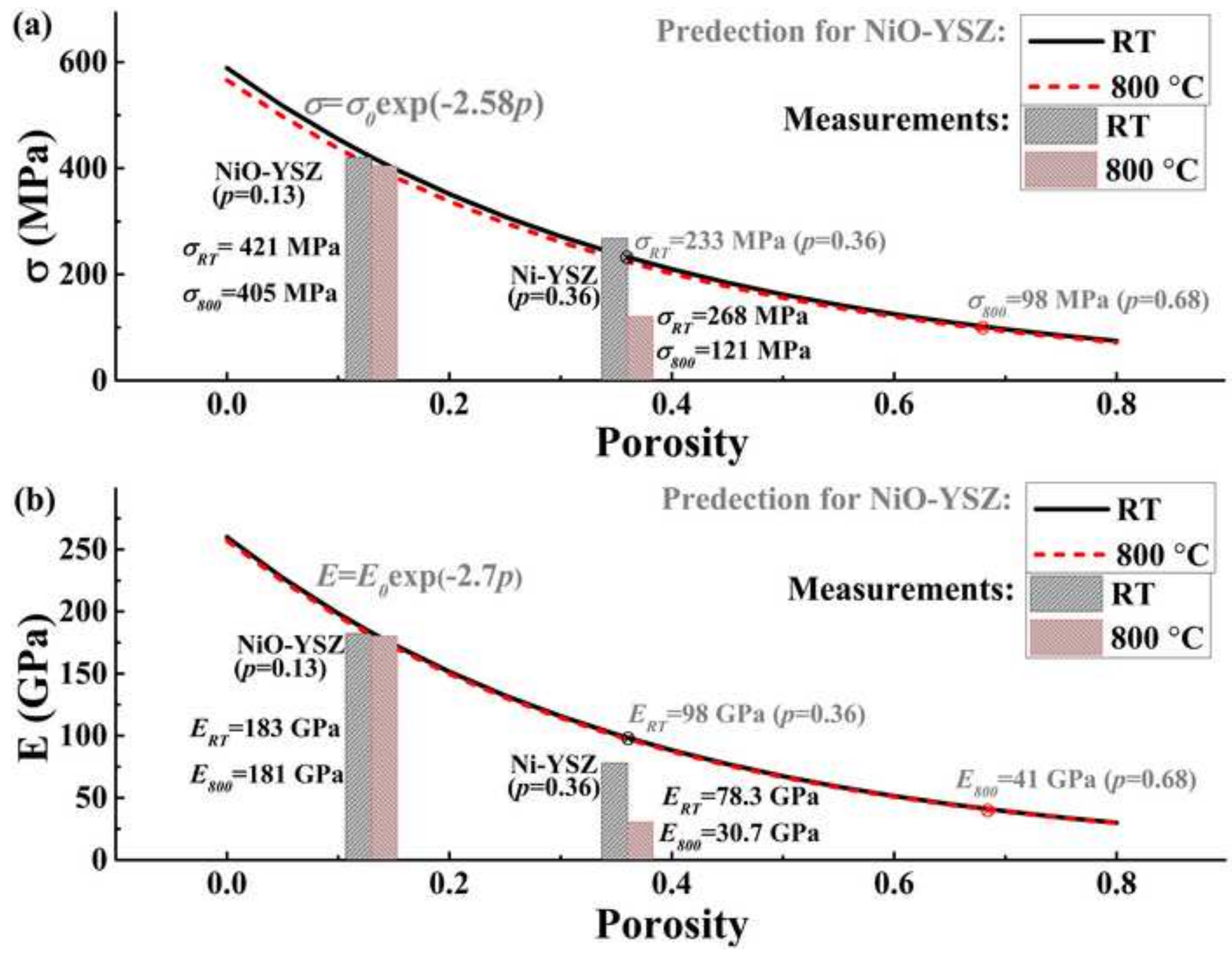

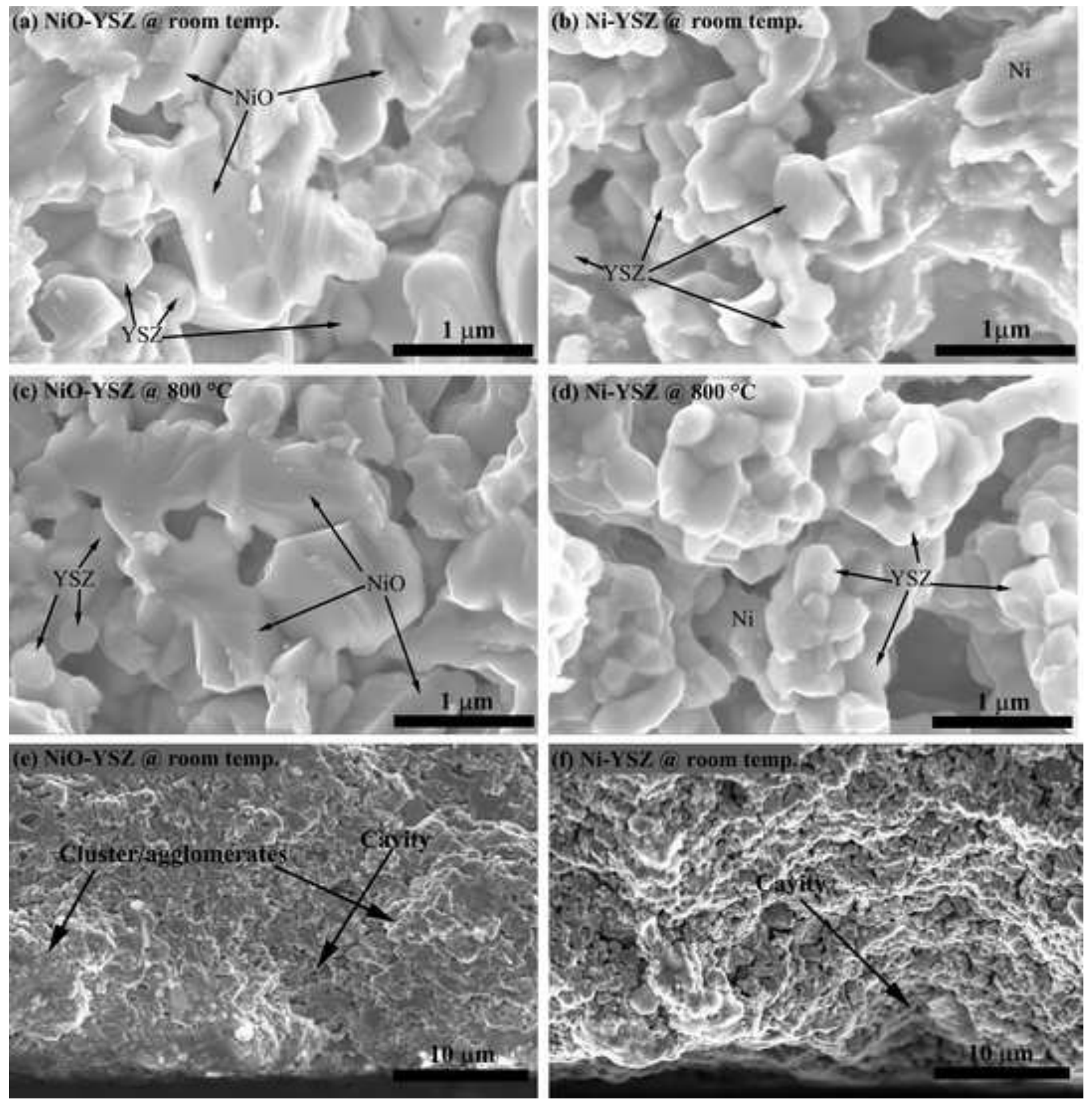